\title{
Modern Nepali Oral Transmissions of Vetālapañcaviṃśati Stories to Europe
}

\author{
Alaka Atreya Chudal | ORCID: 0000-0002-7308-7384 \\ Institut für Südasien-, Tibet- und Buddhismuskunde, \\ Universität Wien, Vienna, Austria \\ alaka.chudal@univie.ac.at
}

\begin{abstract}
This article presents three recitation versions of two tales from the famous Vetālapañcavimśati (VP; the "Twenty-Five Tales of an Animated Corpse", a medieval Sanskrit anthology of riddle-tales) that made their way orally from South Asia to Europe. The original work is one of the rare Sanskrit texts to have been disseminated widely and over a long period of time. It is a work that has thrived in oral, manuscript and printed versions. The stories in question, recorded in Germany as retold by three Nepali prisoners of war during World War I, show how this pre-modern Indian textual tradition was received into modern vernaculars and recounted in modern settings. It documents the fluidity of texts as dependent on the reciter's, scribe's or publisher's own outlook, as well as on differing times and circumstances. In addition to the text's long history of transmission, colonialism and print capitalism were further factors that influenced the retelling of the VP.
\end{abstract}

\section{Keywords}

Vetālapañcavimśati - South Asian folklore - oral transmission - WW I - Gurkha soldiers - textual fluidity

\section{Introduction}

Just as every material product is subject to the effects of time, so too works of literature often undergo reshaping. Such transformation can occur in oral, manuscript or printed mediums, or in combinations of two or more of them. 
Texts were once predominantly transmitted orally, then came the written word, and still later the print medium arose. Each time a text is reproduced, there is a chance for changes to slip in. The personal outlook of the speaker, scribe or publisher can influence a text's development, as can the altered landscape of later times. A source can experience quite major changes, such as of its form or content, its genre or language of transmission. If a text is recast in another language and travels to another culture, the changes may be still greater. This article aims to illustrate such changes based on a text that was transmitted from Sanskrit into various vernaculars, travelled from Nepal to India, and then continued on further from Asia to Europe.

The texts in question are part of the famous Vetālapañcavimśati (henceforth VP), the "Twenty-Five Tales of an Animated Corpse," a medieval Sanskrit anthology of riddle-tales that has made its way into many other languages and spread to other continents. This process started off by the stories in the anthology being translated into South Asian vernaculars from the early eighteenth century onwards. The stories themselves are believed to have originated in the early Sanskrit narrative tradition. In a 1919 study on the Pañcatantra and other such collections, William Norman Brown searched early Sanskrit texts for sources of modern folktales. He concluded that a majority of oral folktales circulating in the vernacular languages of contemporary India could be traced back to classical literary versions written in Sanskrit, a fact that facilitated both their preservation and diffusion. ${ }^{1}$

Stuart H. Blackburn and A.K. Ramanujan ${ }^{2}$ have created a diagram for understanding the many-phased interlacing cycles of transmission that have governed traditional literature in India. There are many paths that such transmission has taken, and not all are clear-cut. For instance, a tale may have originated orally, then was written down by a collector of tales, then the written version was disseminated to another oral teller of tales, who in turn gave rise to a new written or oral version.

In Blackburn and Ramanujan's chart below, the subscript 'c' signifies composition, and ' $t$ ' means transmission. Their diagram suggests that regardless of whether a text was originally written or oral, it can enter a complex web of both types. The diagram serves to clarify the dynamic relationships between

1 Adheesh Sathaye has examined how folk narratives, riddles and proverbs entered and collided with various Sanskrit versions of the VP, offering a thorough analysis of the textual dynamics of one of its stories, "The Wife and the Thief." See Adheesh Sathaye, "The Scribal Life of Folktales in Medieval India," South Asian History and Culture 8, no. 4 (2017): 430-447. doi:10.1080/19472498.2017.1371511.

2 Stuart H. Blackburn and A.K. Ramanujan, eds., Another Harmony: New Essays on the Folklore of India (Berkeley: University of California Press, 1986), 5 . 


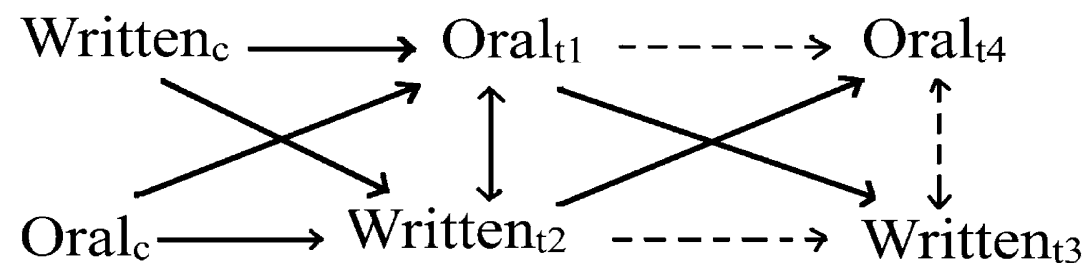

FIGURE 1 A diagram charting possible paths in the oral and written transmission of folklore

REPRODUCED FROM BLACKBURN AND RAMANUJAN, ANOTHER HARMONY, 5

oral sources, written sources, oral retellings and written retellings, whereby each type, over time, might possibly influence all others.

In the context of the twentieth century (the period of our focus), one must add printed publications to the above diagram, and thus include the following hypothetical path: A story that originated orally is then written down by a collector of tales. The collected story becomes part of a rich literary tradition and is thus preserved by scribes over a long period of time. It is then translated into different languages and further preserved in written and then printed form. One of these written or printed versions is then picked up by an oral storyteller, who in turn gives rise to a still newer written or oral version.

A path of this sort can be found in three oral versions, in Nepali, of two different VP stories recorded in Germany during World War I by three Gurkha prisoners of war (henceforth pows), Ait Singh Gurung, Dal Bahadur Gharti, and Gajabal Thapa. Two versions of the same vP story were recounted by Ait Singh and Dal Bahadur, who were originally from the same community, region and profession. Gajabal recounted a different VP story. It is unclear whether these three Pows knew each other in the camp, but in any case they were from the same regiment and housed in the same barracks. The diagram below presents the transformation process of these stories as they emerged in different versions.

One might argue that in the process of transmitting folklore orally, copying manuscripts (as in medieval India) or preparing printed texts, texts are subject to the tastes and whims of their narrators, scribes or publishers. To exemplify this, we shall take the two above-mentioned stories from the VP, "How the Prince Obtained a Wife" and "The Story of the Mixed Relationship," and observe how the Sanskrit text made its way into South Asian vernaculars and then into the above three oral retellings of it in the Nepali language. To analyse the degree of textual fluidity of these two well-known stories, we will compare an 1881 printed Nepali version, an undated Nepali manuscript probably written 


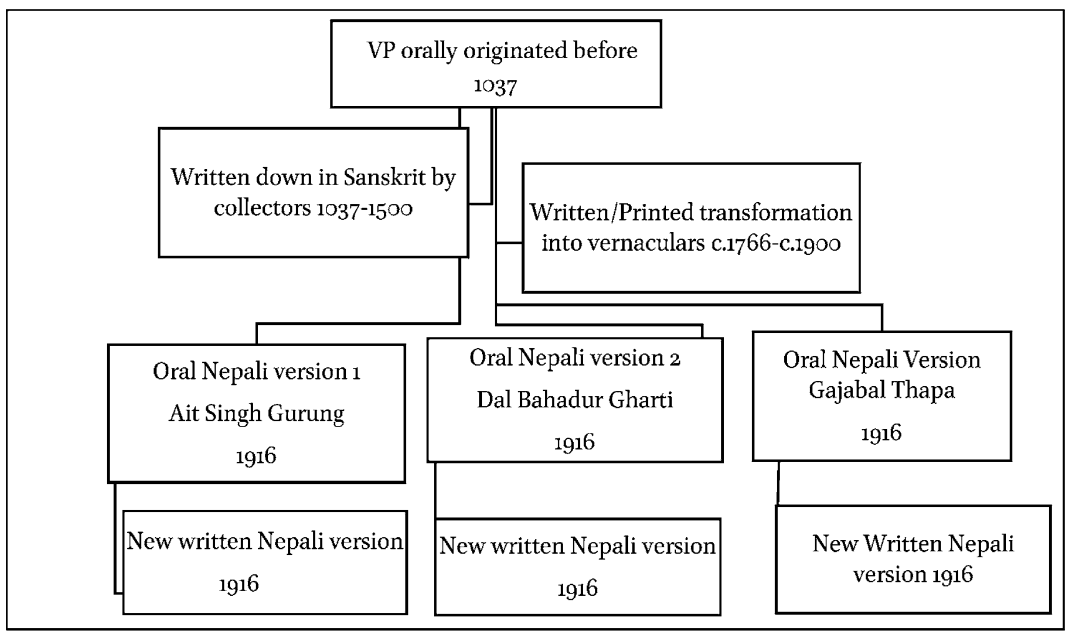

FIGURE 2 Two modern oral and written transmissions of a Vetala story

sometime during the first three decades of the nineteenth century, ${ }^{3}$ and the oral Nepali versions recorded in Europe by the three Pows in 1916.

The Gurkha storytellers had been sent to the battlefields of Europe to fight for the British. They were captured by the Germans and kept in Halbmond camp in Wünsdorf near Berlin. The three men's retelling of the two stories, with their individual styles and structures, also reflect the men's social and cultural context. At the time the recordings were made, more and more Nepali folklore was being written down and published in India. The following analysis will thus also contribute to an understanding of the interaction in South Asia between oral and written modes of discourse, and thus between oral and literary cultures.

A secondary matter that will be examined here is how people from the same country but with different backgrounds, in this case Nepali Brahmins and warrior Gurkhas, are connected through folklore, and how this can influence textual dynamics.

\section{The Storytellers and Their Recordings}

Before getting down to the main analysis, we should first acquaint ourselves a little more with the storytellers, the three Gurkha Pows from western Nepal,

3 Theodore Riccardi, A Nepali Version of the Vetātalañcaviṃśati (New Haven [CT]: American Oriental Society, 1971), 2. 
Ait Singh Gurung, Dal Bahadur Gharti and Gajabal Thapa. ${ }^{4}$ Why were they in Europe, to whom did they recite the VP stories, and why did they record these particular stories as opposed to others?

During World War I, many Gurkhas found themselves sailing across the ocean for the first time in their lives. More than 940,00o South Asian soldiers and labourers serving in the British Indian Army were shipped across the ocean between August 1914 and October $1918 .{ }^{5}$ Records show that of these, some 200,00o were Gurkha soldiers. ${ }^{6}$ One in ten never returned home from the battlefield. ${ }^{7}$ Many departed between September and October 1914 with the first mobilized units of Indian soldiers, landing on the quays of Marseilles and deployed in France and Belgium to support the British war effort. The conditions in Europe were not comfortable for these South Asians, who were used to the subcontinent's warm weather and their own cuisine. In the first thirteen months of service, the British Indian Army saw 21,00o casualties in France. Its soldiers were consequently transferred by the British to Mesopotamia.

In addition to the high number of casualties of World War I, altogether nine million Pows were taken by the two sides during the war. Two and a half million soldiers fighting among the British ranks were captured on the battlefield and imprisoned in Germany. ${ }^{8}$ South Asian soldiers captured by Germany on the Western Front were first taken to various pow camps in Germany, but from the early months of 1915, Indian Pows were kept in Halbmond Camp in Wünsdorf, ${ }^{9}$ about 40 kilometres from Berlin. Since Gurkhas were categorized as Indian soldiers, most were also held in Halbmond Camp. This special camp was set up to keep the South Asian prisoners separate from both French colonial soldiers from North Africa and Russian Pows. Although life was very rough

4 For more details on Ait Singh, Dal Bahadur and Gajabal, see: Alaka Atreya Chudal, Gorkhā $\bar{\imath}$ yuddhabandī kā lokbhākā ra kathā (Kathmandu: Nepal Academy, 2021), and Alaka Atreya Chudal, "Storytelling in Prison: Oral Performance of a Gurkha Prisoner of World War I," European Bulletin of Himalayan Research 54 (2020): 5-36.

5 Ravi Ahuja, "Lost Engagements? Traces of South Asian Soldiers in German Captivity, 19151918," in When the War Began We Heard of Several Kings: South Asian Prisoners in World War I Germany, eds. Franziska Roy et al. (New Delhi: Social Science Press, 2011), 19.

6 Lionel Caplan, Warrior Gentlemen: "Gurkhas" in the Western Imagination (Providence [RI]: Berghahn Books, 1995), 22.

7 David Bolt, Gurkhas (London: White Lion, 1975), 66.

8 Franziska Roy, "South Asian Civilian Prisoners of War in First World War Germany," in When the War Began We Heard of Several Kings: South Asian Prisoners in World War I Germany, eds. Franziska Roy et al. (New Delhi: Social Science Press, 2011), 53.

9 Heike Liebau, "Prisoners of War (India)," in 1914-1918-online. International Encyclopedia of the First World War, eds. Ute Daniel et al. (Freie Universität Berlin, Berlin 2014-10-08), 3. Available at: http://dx.doi.org/10.15463/ie1418.10452, accessed May 20, 2019. 
in the camp and the mortality rate was high, the prisoners in this so-called Inderlager (Indian camp) usually enjoyed better conditions and treatment than those in the normal pow camps. While it was purported to be a special camp requiring heightened measures of security, Berlin citizens were allowed to visit and view its exotic prisoners as though it were a zoo. ${ }^{10}$ Today there is nothing left of the site. However, a few kilometres away, in Zehrensdorf, a cemetery for the Indian Pows still exists and is in good condition, having been restored by the Commonwealth War Graves Commission. ${ }^{11}$

In October 1915, the Royal Prussian Phonetic Commission was established. Staffed by German researchers, its objective was to make systematic recordings of the languages, music, phonetic sounds and stories representative of the countries of origin of POWs and to compile a comprehensive sound archive of the world's languages. ${ }^{12}$ To complement the phonographic corpus, the members of the commission produced transcripts of the recordings in the native scripts and translations into German, which were filed together with personal data of the recorded prisoners and metadata about time, location and type of recording. ${ }^{13}$ The process, aim and restrictions of the recordings in Germany of the South-Asian Pows and the propaganda efforts among them has already been discussed in detail in earlier studies, ${ }^{14}$ so here we will concentrate on our three protagonists and their recorded stories.

Altogether nineteen Gurkha Pows imprisoned in Halbmond Camp recorded remembered stories in Nepali for the commission. In addition to these recordings, the archives contain manuscripts of six folktales for which no recording was made. ${ }^{15}$ Three stories in this precious collection, those recorded by Ait Singh, Dal Bahadur and Gajabal, have been found to have the VP as their source.

Ait Singh ${ }^{16}$ and Dal Bahadur both came from Tahsil No. 2, West Nepal; Gajabal came from Tanahu district. Ait Singh was a member of the Gurung

10 Britta Lange, "South Asian Soldiers and German Academics: Anthropological, Linguistic and Musicological Field Studies in Prison Camps," in When the War Began We Heard of Several Kings: South Asian Prisoners in World War I Germany, eds. Franziska Roy et al. (New Delhi: Social Science Press, 2011), 172.

11 Details may be found at: https://www.cwgc.org/find-a-cemetery/cemetery/34721/ZEH RENSDORF\%2OINDIAN\%2OCEMETERY, accessed April 22, 2021.

12 Wilhelm Doegen, Unter fremden Völkern: eine neue Völkerkunde (Berlin: Stollberg, Verl. für Politik u. Wirtschaft, 1925), 10.

13 The Sound Archive of Humboldt University of Berlin has preserved the records and files in a digitized format.

14 Franziska Roy et al., eds., When the War Began We Heard of Several Kings: South Asian Prisoners in World War I Germany (New Delhi: Social Science Press, 2011).

15 Chudal, Gorkhālīyuddhabandī.

16 For a separate account of his life and his recordings, see Chudal, "Storytelling in Prison." 
ethnic group, whereas Dal Bahadur and Gajabal belonged to the Magar ethnic group. All three served as riflemen in the 4 th Gurkha Rifles in India. In data collected at some unknown date prior to the voice recordings, Ait Singh's age is given as $33,{ }^{17} \mathrm{Dal}$ Bahadur's as $26,{ }^{18}$ and Gajabal's as $39 .{ }^{19}$ The personal files filled out on the day of the recordings state that at the time they were 35,27 , and 39 years old, respectively.

All gave Gurkhali as their mother tongue and claimed an ability to speak Hindustani along with a proficiency in reading and writing the Devanagari script. Dal Bahadur did not speak his ancestral tongue (Magar), but Ait Singh and Gajabal were also able to speak their ethnic mother tongues (Gurung and Magar, respectively). All three practised the Hindu religion, and their profession was farming. They did not play any musical instruments. While they had never gone to school or received any formal education, their ability to read and write Devanagari script suggests that they learned these skills either on their own, or in the regiment during their preliminary training.

Of our three storytellers, Gajabal returned home from Europe, ${ }^{20}$ Ait Singh died in the camp, and Dal Bahadur is neither on the list of dead soldiers nor on the list of his fellow fighters who sailed back to their homeland in 1919. However, a photo of him is found in the Heinrich Lüders ${ }^{21}$ Collection in the Archive of the Berlin-Brandenburg Academy of Sciences and Humanities. ${ }^{22}$

In the afternoon of 29 May 1916, the German scholars of the Phonographic Commission led Ait Singh and Gajabal through the recording process. The recording of Ait Singh needed four cylinders, but the second is missing in the archive. The available three cylinders contain episodes of a single story and run altogether $06: 03$ minutes. Gajabal's story is the shortest of the three recordings. His story was recorded on only one cylinder and runs 01:51 minutes. Dal Bahadur's story was recorded a week later, on 6 June 1916, on two cylinders. Altogether his voice recording runs for 05:56 minutes.

17 Heinrich Lüders Collection (Nachlass [NL] Heinrich Lüders): NL Lüders Nr. 1: Bd. 4, p. $5^{8}$.

18 NL Lüders Nr. 1: Bd. 3, p. 58.

19 NL Lüders Nr. 1: Bd. 4, p. 51.

20 His name is found on a list based on a document of the Indian Soldiers Fund preserved in the British Library, London: IOR MSS EUR F12D/272.

21 Heinrich Lüders was the German Indologist in charge of making recordings of South Asian pows. For details about his role in making the recordings, see Lange, "South Asian Soldiers and German Academics," 157-161. See also Chudal, "What Can a Song," and Chudal, "Storytelling in Prison." NL Lüders, Nr. 3 Bd. 2 p. 13. 
TABLE 1 Details of the recordings

\begin{tabular}{|c|c|c|c|}
\hline Name & $\begin{array}{l}\text { Date of } \\
\text { recording }\end{array}$ & $\begin{array}{l}\text { Record numbers: } \\
\text { duration }\end{array}$ & $\begin{array}{l}\text { Total duration } \\
\text { of recording }\end{array}$ \\
\hline Ait Singh Gurung & 29 May 19161 & $\begin{array}{l}\text { PK246: 02:32 minutes } \\
\text { PK250: 01:59 } \\
\text { PK251: 01:56 }\end{array}$ & o6:03 minutes \\
\hline $\begin{array}{l}\text { Dal Bahadur } \\
\text { Gharti }\end{array}$ & 6 June 1916 & 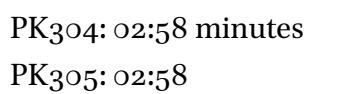 & 05:56 minutes \\
\hline Gajabal Thapa & 29 May 1916 & PK 248/2: 01:51 minutes & 01:51 minutes \\
\hline
\end{tabular}

\section{The Transformation of the VP's Riddle-tales into South Asian Vernaculars and Abroad}

Before examining the Pows' stories, we should first consider the transformation of the VP's riddle-tales from the original Sanskrit into Indian vernacular versions, and later into European languages.

It is likely that the four major Sanskrit versions of these stories, thought to have been rooted in an oral tradition, were composed in the first half of the second millennium. ${ }^{23}$ The version composed in combined prose and verse by Shivadasa from Gujarat in c. $1200 \mathrm{CE}$ became the most popular, and it was translated into a number of vernaculars in India. For example, Surati Mishra translated Shivadasa's Sanskrit version into Braj Bhasha prose under the title Baitāl Pacīsi in about 1700. This in turn was translated into Hindi (in 1805) under the same title by Lallu Ji Lal, assisted by Mazahar Ali Khan Wila, for use in language courses for East India Company staff officers at Fort William College, Calcutta. Because of its quite Sanskrit-like language, the text was later simplified by Tarini Charan Mitra. In 1857 Duncan Forbes published another revised and simplified version of it in Hindustani (containing more Persian-Urdu influences). ${ }^{24}$

Surati Mishra's earlier Braj Bhasha translation opened the door for the Sanskrit VP to be introduced into printed book form in other Indian vernaculars. Also English and German translations were published in Europe already in

23 Sathaye, "The Scribal Life of Folktales," 3.

24 Duncan Forbes, The Baitāl Pachīsī; or, the Twenty-five Tales of a Demon (London:W.H. Allen, 1857), v-vi. 
the nineteenth century, before Ait Singh, Dal Bahadur and Gajabal arrived and recorded their version of two of its stories in Nepali. Early versions of the VP published in Europe include John Platts's English translation of 1871 (based on the version of Forbes), Captain Sir Richard F. Burton's 1870 English translation, and an 1881 German commentary on manuscripts of the popular Shivadasa version by Heinrich Uhle. Shivadasa's version of the VP has proverbial verses known as subhāsitas throughout the text that are not found elsewhere, even in the vernacular translations.

Early records of a Nepali manuscript version of the VP go back to 1798, a translation of Gauri Shankar Pandit's Vetāla Pañcavimśatikatha ${ }^{25}$ which was apparently in Sanskrit. In 1811, a Newar resident of Kathmandu valley named Amritananda ${ }^{26}$ translated Shivadasa's version of the VP into Nepali. ${ }^{27}$ Another Nepali adaptation of the VP in poetry that is full of Nepali elements was composed by Udayananda Arjyal in $1815 .{ }^{28}$ In 1828 , Tulasi Ram Sigdyal also translated the Sanskrit VP into Nepali. Another unnamed Nepali translation of the vP from 1836 is also available. ${ }^{29}$ The Nepalese German Manuscript Cataloguing Project (NGMCP) has microfilmed almost sixty ${ }^{30}$ different versions of handwritten manuscripts of the VP found in Nepal. These microfilmed manuscripts are in Newari, Sanskrit and Nepali, however, the majority are in Newari. Incomplete manuscripts are found under the titles Pañcavimśativetāla, Vetālakathā and Vetāla[pañcaviṇśatikathā], most with dates and translators not mentioned. A few manuscripts do have dates on them, such as five Newari manuscripts from 1691, 1695, 1712, 1763 and 1772, a Sanskrit manuscript from 1630 and a Nepali manuscript from 1798 . Theodore Riccardi refers to altogether ten VP manuscripts in Nepal, of which four are in Newari and six in Nepali. ${ }^{31}$ According to him, only one Nepali manuscript is complete; it is dated AD 1816. Most of the manuscripts found in Nepal are based on the Sanskrit versions of Shivadasa and Jambhaladatta.

A printed version of a Nepali VP was available on the Indian market already by the end of the nineteenth century, but it is again difficult to trace its first

25 Indrabahadur Chhetri, "Darjīlinkāa nepālī kathāharūko pravṛttigat viśleṣaṇ ra mūlyāñkan (san 1938-196o)" (PhD Diss., University of North Bengal, 2003), 41.

26 Amritananda also assisted Brain Houghtan Hadgson during his Nepal stay 1820-1843.

27 Dayaram Śhrestha, "Prārambhik kālko Nepālī sāhityako pūrvapịṭikā," in Jagadambā Nepāli Sāhityako Bṛhat Itihās, ed. Mādhav Prasād Pokhrel (Lalitpur: Kamalmani Prakashan), 473 .

28 Śhrestha, "Prārambhik kālko Nepālī sāhityako pūrvapīthikā," 451.

29 Śhrestha, "Prārambhik kālko Nepālī sāhityako pūrvapịṭikā," 5oo.

30 Source: The Nepalese German Manuscript Cataloguing Project (NGMCP) microfilm online catalogue.

31 Riccardi, A Nepali Version of the Vetātalañcaviṃśati, 1. 
publication date. Nepali versions of the VP were published in Benares by Nepali print entrepreneurs who had migrated there from Nepal. ${ }^{32}$ These Nepali entrepreneurs mainly printed three literary genres: religious literature, erotic poetry and folktales. Religious literature dominated the Nepali printing sphere. The Nepali print entrepreneurs in Benares also published a great deal of lahari poetry, which had entered the Nepali literary realm and secured a place for itself within the romantic/erotic genre. ${ }^{33}$ Much of such popular romantic lahari poetry features lahures (Gurkha soldiers in the British Indian Army) and the life they led. ${ }^{34}$ The third interest of Nepali print entrepreneurs were folktales based on stories found in Hindi, Sanskrit, Arabic and Farsi sources. ${ }^{35}$ Such entrepreneurs had virtually free rein when it came to popular literature: they picked up a circulating book, made some very minor changes to it, or sometimes none at all, and printed it under their own name. This is why many printed versions of the VP in Nepali from this period mention neither a publication date nor an author or translator, but do carry the name of the publisher. The text, the publishers, and the storytellers belong to a period when copyright was not an important concern.

In 1971, Theodore Riccardi published a Nepali version of the VP with an introduction, grammatical explanation of the language used and notes on the text, together with an English translation of the Nepali part of a manuscript originally in both Sanskrit and Nepali, whose date and translator were again not mentioned. It is worth noting here that Riccardi used the Nepali manuscript of the VP that was originally from Benares. It was donated by Professor W. Norman Brown to the University of Pennsylvania library. This VP manuscript was obtained by Brown from Narayan Shastri Khriste ${ }^{36}$ in Benares. Brown also published an important work on how the Pañcatantra and other such collections became the sources for modern folktales. This is another piece of evidence of Nepali manuscripts of the VP being first transmitted to

32 For more details on Nepali print entrepreneurs, see: Alaka Atreya Chudal, "Nepali Intellectuals in Exile: The History of Nepali Printing in 19th-2oth Century Benares," Journal of South Asian Intellectual History 3 (2021): 1-26.

33 The most prominent bestsellers of the period were Ānanda Laharī, Prem Laharī, and Madan Laharī.

34 For the folksongs of Pows, see Alaka Atreya Chudal, "What Can a Song Do to You? A Life Story of a Gurkha Prisoner in World War I," South Asia:Journal of South Asian Studies 43, no. 3 (2020), and Chudal, Gorkhālìyuddhabandī.

35 Such as in Vìrsikkā, Lālhirā, Madhumālati, Betāl Paccīsī, Siṃhāsanbattīsī, Hātimtī, Gulbakavali, Gulsanovar and Hitopadeśa.

36 W. Norman Brown studied with Narayan Shastri Khriste in Benares. See Baladev Upādhyāya, Kāśi kī pāṇditya paramparā (Vārāṇasī: Viśvavidyālaya Prakāśan, 1994), 373. 
Benares, to be published there. In this case the manuscript found its way to the United States.

As mentioned above, in the early printing period, texts in Nepali were published in Benares by migrant Nepali print entrepreneurs. ${ }^{37}$ Printing and publication of Nepali books could not flourish in Nepal due to limited press rights, as well as unavailable resources for printing. This early Nepali printing history is not very different from the Hindi printing history in India. Francesca Orsini has analysed Hindi printing activities in early twentieth-century India ${ }^{38}$ and identified a significant formula in the print culture, namely, reproduced genres and introduced genres. As Orsini notes, Hindi and Urdu books published in the last decades of the nineteenth-century in North India consisted mainly of reproduced genres, that is, genres rooted in either oral or manuscript cultures that then experienced wider and more generalised transmission through mechanical reproduction. A majority of books in early Nepali print history also comprise reproduced genres. The books printed in Benares in the last decade of the nineteenth and the first half of the twentieth century are not well preserved, and as mentioned above, their editions and first publishing dates were not always noted, which makes it difficult to trace their publication history. However, since we have evidence of a large number of VP manuscript collections in Nepal and we also find evidence of VP texts published in Nepali, the VP seems to be a reproduced genre in the Nepali print market in India. Moreover, it also seems that the VP in Nepali was popular reading material and thus a profitable print commodity for the Nepali print entrepreneurs in Benares. Indeed, the British Library holds four different early editions of Nepali vPs published in the first three decades of the 19th century by three different publishers. ${ }^{39}$

An early twentieth-century study by Sir George Abraham Grierson used an introductory chapter (the frame story) of a published Nepali version of the VP as an example of Khas-kura (or "Naipalī")..$^{40}$ The source is anonymous; as described above, most books printed during this period do not bear a publication date or the author's name. The text used by Grierson is the same one as found in the Baitäl Pacis̄il, the early title used for the VP, published by Harihar

37 Chudal, "Nepali Intellectuals in Exile."

38 Francesca Orsini, "Detective Novels: A Commercial Genre in Nineteenth-century North India," in India's Literary History: Essays on the Nineteenth Century, eds. Stuart Blackburn and Vasudha Dalmia (Delhi: Permanent Black, 2004), 435-482.

39 Divākar Śarmā, Kāshī: 1924, Baijnāth-prasād, Banāras: 1924, Śivaprasād Rāghorām, Benāras: 1927 \& 1936.

40 G.A. Grierson, Linguistic Survey of India, part IX, vol. IV (Calcutta: Superintendent of Government Printing, India, 1916), 69-74. http://dsal.uchicago.edu/books/lsi/lsi.php ?volume=9-4\&pages=998\#page $/ 1 /$ mode $/$ iup, accessed October $17,2017$. 
Sharma of Gorkha Pustakalaya in Varanasi. While this Varanasi volume also contains neither publication date nor name of the translator, in the text itself, in a line of verse, it does state that the text was composed in the year 37. This is likely 1937 Vikram Samvat, which would place its composition sometime in 1881/1882. Grierson mentions a printed abridged version of the Baitäl Pacīsi put out by Gorkha Bharat Jivan Pustakalaya, a publisher of Nepali books in Benares ${ }^{41}$ and that this was the work he took his sample text from. ${ }^{42} \mathrm{He}$ emphasizes that this translation, by an anonymous author-translator, was meant for native speakers. Nepali-language publications in India, and in Varanasi in particular, got off the ground with Vishvaraj Harihar establishing the Durga Press [Gorkha Pustakalaya] in Varanasi in 1881. Many of his publications, including Baitāl Pacīsī, became bestsellers. ${ }^{43}$

This shows that the twenty-five VP stories were popular during this period. And as shown by Grierson's use of the VP, it was also important for Indologists abroad. Moreover, there is evidence that army recruits were often the consumers of these publications. A Hindi version of the VP stories was one of the texts used in the examinations of candidates for military service in the East India Company. ${ }^{44}$ For publications in Nepali, the Gurkha regiments in India were the main market, given that they constituted the bulk of the Nepali-speaking population in India around the turn of the century in $1900 .{ }^{45}$ While we were unable to find any evidence of the VP stories being used in particular as reading texts for Gurkha soldiers during their regiment training, nonetheless it was a popular text among Gurkha recruits. The Baitāl Pacīsı̀ was also standard and popular reading material among British staff officers learning the language of their Indian and Nepali recruits. Moreover, the text was widely copied and translated, with manuscripts found in Sanskrit as well as vernacular languages such as Newari and Nepali, and it was attractive and profitable printing material for the Nepali print entrepreneurs in Varanasi. Riccardi also mentions

41 The Hindi publishing house Bharat Jivan Press brought out a number of Nepali books in Varanasi at the request of the extremely active contributor to Nepali literature Motiram Bhatta (1866-1896), who also worked there for some time. The publishing house continued to exist after Bhatta's death. It may have printed the same text as the above-mentioned Gorkha Pustakalaya. It is also possible that Grierson confused the one for the other.

42 Grierson, Linguistic Survey of India, 20.

43 Gupta Pradhan, Dhümil prșțhaharū (Darjeeling: Gama Prakashan, 2008), 200.

44 W. Burckhardt Barker and E. Backhouse Eastwick, The Baitál Pachísi; or, Twenty-five Tales of a Demon: A New Ed. of the Hindí Text, with Each Word Expressed in the Hindústáni Character Immediately under the Corresponding Word in the Nágarí; and with a Perfectly Literal English Interlinear Translation, Accompanied by a Free Translation in English at the Foot of Each Page, and Explanatory Notes (Hertford: S. Austin, 1855), vi.

Grierson, Linguistic Survey of India, 19. 
that the VP stories enjoyed wide popularity in earlier days, as can also be seen by the popular Nepali idiom baitāl pacisis padheko manche, "a man who has read the Baital Pacisi," i.e., a clever person. ${ }^{46}$ All of this evidence shows that the stories of the VP were well known in Nepali society in the period in question.

Indeed, the major customers targeted by publishers of Nepali books in India, and in Benares in particular, were the Gurkha Rifles, since among Nepali residents in India, it was military recruits who had cash to purchase books. However, it is not possible to know whether our storytellers themselves had ever read a printed Nepali version of these stories. One might speculate as likely that while learning to read and write in their regiment, they had access to a copy of Baital Pacisi sold or available at the regiment headquarters. ${ }^{47}$ They may have listened to someone read it aloud, or they may well have read it themselves, given their mastery of Devanagari. But the VP stories were also circulated orally in villages, so is also possible that our protagonist pows had heard them at home and memorised them to prove themselves clever, as described above in Riccardi's quote of the Nepali idiom. The stories recited by Ait Singh and Dal Bahadur are, in any case, much briefer than the original Sanskrit or the translated vernacular versions of that period. Moreover, the printed Nepali version of the stories is in verse, verses that are relatively stable and easy to memorise. But Ait Singh, Dal Bahadur and Gajabal recited in prose, and in a colloquial form of Nepali at that. We can assume that it was not possible for our storytellers to memorise the text exactly, even if they had read the story in verse. Another factor is that alongside the printed Nepali versions of the VP, during that period the prose version of manuscripts was also popular and indeed, more likely in setting of communal/community storytelling. We might further argue that our protagonists did not remember the exact verses, but the story was known to them and thus they retold the story from memory in prose, with deviations of course of their own making. It is also possible that since they were in captivity, when asked to recite a story they recited a story their interlocutors were familiar with. This argument would explain why the same vP story was recited by the two soldiers Ait Singh and Dal Bahadur.

Before examining the stories themselves, a central question must be asked: Should these audio recordings be treated as oral versions, since transcripts were also created in the Pow camps alongside the recordings? As already

46 Riccardi, A Nepali Version of the Vetātalañcaviṃśati, 2.

47 There is good reason to assume that Ait Singh knew a Nepali version. In his recording he introduces the main female character as being from Kanpur in Uttar Pradesh, whereas in the Hindi and Sanskrit versions she is from Karnataka. The published Nepali versions read Karṇapura, from which Kanpur derives. 
mentioned, in Nepal the VP stories were so popular that knowing them was a mark of cleverness. Against this backdrop, the Gurkha Pows from the West Nepal who were in Europe carried those stories with them in their memory, and thus were carrying an oral tradition of the VP to Europe. Nonetheless, there is a high possibility that the Pows had encountered a printed version of the VP stories while in India. If they had, these printed versions refreshed their memory of the VP stories heard at home. They thus reached Europe with stories in their memory that were also part of a written tradition. In the pow camp these stories were first related orally and then transcribed in writing under the instructions of the German scholars. In reference to A.K. Ramanujan, ${ }^{48}$ we thus might say that the Pows were involved in a complex cycle of transmission, a cycle comprised of oral, written, printed, oral and written. When our pows first encountered the VP stories, they had already completed a cycle of oral and written transmission. They received the VP stories through oral performance and then, in India, they read or heard a printed version. Finally, in the Pow camp they provided an oral version of the story, and then wrote it down. Thus we can say that the Pows' transmission of the VP stories to Europe was oral. ${ }^{49}$

\section{The Oral Transmission of the VP Stories}

The VP is a collection of stories told by a vampire or an evil spirit that inhabits and re-animates dead bodies. It is a collection of old and thoroughly Hindu plots. The stories mainly deal with a king named Vikramaditya who, in order to fulfil a promise to an ascetic, must bring him a corpse from a tree and carry it to a cremation ground, where he has to perform certain rites. The difficulties King Vikramaditya encounters in doing this are the leitmotif of the VP. As the king carries the dead body on his back, the Vetala, the evil spirit, enters the corpse and begins to tell a series of stories to the king. Each story comes with a riddle. If the king answers it correctly, the corpse vanishes back to the original tree. When the king goes back to fetch it, the Vetala starts telling another story. The process is repeated twenty-five times. While the sequence of the stories in the early Sanskrit versions of the Vetalapañcavimśati differs slightly, in the later manuscripts and printed vernacular versions, the stories of our concern, "How the Prince Obtained a Wife" and "The Story of the Mixed Relationships,"

\footnotetext{
48 A.K. Ramanujan, "Who Needs Folklore? The Relevance of Oral Traditions to South Asian Studies," South Asia Occasional Paper Series, no. 1 (Hawaii: University of Hawaii, 199o), $11-12$.

49 See figure 2 above.
} 
are the first and twenty-fourth. ${ }^{50}$ In the following, we will summarise these two stories according to the Nepali manuscript translated by Riccardi.

\section{a) "How the Prince Obtained a Wife"}

\section{Summary}

The tale is about a prince of Varanasi named Vajramukuta, the son of King Pratāpamukuța. One day the prince, accompanied by his minister's son Buddhiśarīra, went hunting far away in a jungle, where he saw a lake filled with blooming lotuses amidst beautiful natural surroundings. The two tethered their horses and sat in the shade of a tree to rest. An unknown young woman accompanied by a host of attendants came to bathe. Seeing each other, the prince and the young woman, who was a minister's daughter, fell in love. The clever young woman took a lotus flower from her hair, placed it on her ear, bit it with her teeth, crushed it with her foot, placed it between her breasts, turned her head towards him and looked at him, and departed for home on an elephant. She was so overcome by love that she became thinner day by day. The prince, too, lost desire for food and pleasure. He decided that if he did not obtain the young woman, he would die. The minister's son had seen the young woman's gestures in the forest and explained them to the prince as follows:

- Taking a lotus and putting it on her ear: There is a King named Karnotpala in Kalinga.

- Biting it with her teeth: He has a minister named Dantaghātaka.

- Crushing it under her foot: Her name is Padmāvatī.

- Pressing it to her bosom: She loves you.

- Turning her face and looking at the prince: Summoning you to her.

The prince and the minister's son got dressed and, on the pretext of going hunting, went to Kalinga in search of Padmāvatī. First they visited the house of Padmāvatī's nurse. They sent the latter to Padmāvatī as their messenger. The prince then visited Padmāvatī. She kept him concealed during the day, and they enjoyed the nights together. Some days went on like this, and the young woman would not permit her guest to depart. The prince remembered his friend, the minister's son, and shared his thoughts with her. She thereupon sent him for a short time to return to his friend with a gift of some poisoned food.

50 Jacob Schmidt-Madsen, "Repossessing the Past: Authorial Tradition and Scribal Innovation in Śivadāsa's Vetālapañcaviṃśatikā," (Unpublished article, 2014), 104-105. Available at: https://www.academia.edu/1375526o/Repossessing_the_Past_Authorial_Tradition_and _Scribal_Innovation_in_\%C5\%gAivad\%C4\%81sas_Vet $\% \mathrm{C}_{4} \% 81$ lapa $\% \mathrm{C}_{3} \%$ Bicavi $\% \mathrm{E}_{1} \% \mathrm{~B}$ $9 \% 83 \% \mathrm{C}_{5} \% 9$ Batik\% $4 \% 81$, accessed May 12, 2018. 
The minister's son refused to eat it, giving it instead to a dog, which promptly died. The prince exploded with rage.

Both were thinking of ways to take Padmāvatì away. In the meantime, the news travelled throughout the city that the son of King Karnotpala had died. The minister's son suggested that he visit Padmāvatī, make love to her and, when she would fall asleep, draw the three lines of a trident on her left thigh with his fingernails and come back with her jewellery. The prince complied, and the minister's son changed his appearance to look like an ascetic and stayed at the burning grounds near the forest. The prince became his disciple. As instructed by the minister's son, the prince went to the market and displayed the jewels at different places. The king's men saw them and asked how he had gotten them. He replied that only his guru knows. The king's men went to meet the ascetic, but he told them he would disclose this only in front of the king. The king went to the burning grounds and asked the ascetic. The ascetic replied: "The daughter of the minister, Dantaghāttaka, is in reality a demoness. Every night she prowls about naked and devours a child. Last night she ate a child with royal marks and brought it to the burning grounds. I angrily struck her left thigh with my trident and, putting her under my power, took her jewels. If she is allowed to remain in the city, no child will remain safe." The King was overcome by anger and, with sorrow for his son, sent some trusted women to examine Padmāvatî's body. They saw the sign on her body and believed her to be a demoness. The ascetic suggested that since women should not be killed, Padmāvatī should be driven out of the country. Alone, Padmāvatī wandered into the forest. The prince, dressed in his own attire, went to the forest. He explained everything to Padmāvatī and took her to Varanasi. They reached there and had manifold pleasure with each other. Padmāvatìs father Dantaghătaka was no longer trusted by the king and exiled. He died of grief over being separated from his beloved daughter, and his wife followed him into the fire.

Now comes Vetala's riddle: The minister and his wife died of grief over their daughter. Who was guilty of their death?

\section{b) The Story of the Mixed Relationship}

\section{Summary}

The story is about King Dharmasiṃha of Dharmapura, his wife Candrāvatī, and his daughter Lāvanyavatī. A king from another country attacked and they fought a big battle. Dharmasimha's army, kinsmen and ministers went to the enemy's side and so he was defeated. Taking his queen and princess, the king fled into a big forest. They reached a village of Bhillas. The king was wearing a shining crown studded with jewels. The Bhillas attacked to steal the jewels 
and the king was killed. Seeing the king killed, the queen and princess fled into another forest.

At this very time it happened that Candrasena, a king, entered that very forest for hunting, accompanied by his son. The father was surprised to see traces of footsteps and showed them to his son. The son suspected them to be made by women. Both decided to search for these women and made an agreement that the father would take the woman with the long feet, and the son the one with the short feet. They finally discovered the women in the jungle and brought them home. The one with the small feet turned out to be the mother and the one with the long feet was her daughter. Nonetheless, remembering the agreement made earlier, the father married the daughter and the son made the mother his wife.

Now comes the Vetala's riddle: How are the children born into the line of these two people related to each other?

\section{Textual Dynamics: the Pows' Different Versions of These Stories}

While the printed Nepali vernacular versions are quite similar to the above earlier versions of these stories, they are often shorter, since various descriptive parts are not included. We now turn to the two different versions of the story "How the Prince Obtained a Wife" recounted by Ait Singh and Dal Bahadur, and the version of the story "The Story of Mixed Relationship" recounted by Gajabal. ${ }^{51}$ As happens in oral traditions, stories are not fixed and unchangeable pieces; each storyteller is free to own the story he or she is telling, and to attempt to make it relevant to the audience through improvisation, omission, or addition of information as necessary. Our POW Gurkha storytellers also did this in their narrations.

The Pows' retellings are closer to the Nepali translation of Shivadasa's version of the VP stories. In contrast to the original Sanskrit or the regular vernacular versions, which describe a wealthy prince of Varanasi and his best friend, a minister's son, Ait Singh's version features a poor king of unknown provenance and his minister. Dal Bahadur's version features a prince and minister's son, similar to the Sanskrit and vernacular versions. Both recordings recount the main element of the story, namely, what happens when the royal protagonist falls in love with the princess during an encounter with her away from his palace. No words are exchanged at the time, but before leaving the princess conveys information about herself through mysterious gestures.

$5^{1} \quad$ For a full transliteration and translation of Gajabal's narration, see Appendix 3. 
These gestures are explained differently by the storytellers. In both recordings, the suitor finds the princess with the help of his minister or minister's son, accuses her of being a witch and proves this to her father, who expels her, thus enabling the suitor to finally marry her. The table below recapitulates the four Nepali versions of the story. Empty boxes indicate the absence of a scene in that particular version.

TABLE 2 A comparison of the narratives in four different versions of the Vetala story "How the Prince Obtained a Wife"

\begin{tabular}{|c|c|c|c|c|}
\hline $\begin{array}{l}\text { Story } \\
\text { element }\end{array}$ & Nepali manuscript $^{a}$ & $\begin{array}{l}\text { Nepali printed } \\
\text { version }^{\mathrm{b}}\end{array}$ & $\begin{array}{l}\text { Oral version } 1 \\
\text { Ait Singh Gurung }\end{array}$ & $\begin{array}{l}\text { Oral version } 2 \\
\text { Dal Bahadur Gharti }\end{array}$ \\
\hline $\begin{array}{l}\text { City and } \\
\text { protago- } \\
\text { nists }\end{array}$ & $\begin{array}{l}\text { Vajramukuta } \\
\text { (Prince of Varanasi) } \\
\text { Buddhiśarīra (minis- } \\
\text { ter's son) } \\
\text { Padmāvatī (daughter } \\
\text { of Dantaghātaka, a } \\
\text { minister of Kalinga) } \\
\text { Padmāvatī's wet nurse } \\
\text { (King Vikramaditya } \\
\text { and the Vetala appear } \\
\text { at the end.) }\end{array}$ & $\begin{array}{l}\text { Mukuțaśekhara } \\
\text { (Prince of Varanasi) } \\
\text { Minister } \\
\text { Padmāvatī (Daughter } \\
\text { of Dantaghātaka) } \\
\text { A garland } \\
\text { supplier lady } \\
\text { (King Vikramaditya } \\
\text { and the Vetala appear } \\
\text { at the end.) }\end{array}$ & $\begin{array}{l}\text { A poor king from } \\
\text { parts unknown } \\
\text { Minister } \\
\text { Padmāvatī (Princess } \\
\text { of Kanpur) } \\
\text { Padmāvatī's wet nurse } \\
\text { (King Vikramaditya } \\
\text { and the Vetala are not } \\
\text { mentioned.) }\end{array}$ & $\begin{array}{l}\text { A prince from an } \\
\text { unnamed country } \\
\text { Minister's son } \\
\text { Padmāvatī (Princess of } \\
\text { Dantapur) } \\
\text { King's wet nurse } \\
\text { (King Vikramaditya } \\
\text { and the Vetala are not } \\
\text { mentioned.) }\end{array}$ \\
\hline Scene 1 & $\begin{array}{l}\text { The prince and min- } \\
\text { ister's son go hunting } \\
\text { far away in a dense } \\
\text { forest. Having killed } \\
\text { fierce lions and other } \\
\text { animals they go along } \\
\text { and see a forest grove. } \\
\text { Within it they see } \\
\text { beautiful birds and a } \\
\text { lake filled with bloom- } \\
\text { ing lotuses. They } \\
\text { tether their horses and } \\
\text { sit in the shade of a } \\
\text { tree to rest. }\end{array}$ & $\begin{array}{l}\text { The prince and } \\
\text { minister go hunting } \\
\text { in a jungle and see } \\
\text { birds and a pool with } \\
\text { colourful flowers. The } \\
\text { prince gets off his } \\
\text { horse, drinks some } \\
\text { water and rests. }\end{array}$ & $\begin{array}{l}\text { The king and his } \\
\text { minister visit a fair on } \\
\text { Monday, a new moon } \\
\text { day. The minister falls } \\
\text { asleep but the king } \\
\text { remains seated under } \\
\text { a tree close to the fair's } \\
\text { bathing ghat. }\end{array}$ & $\begin{array}{l}\text { The prince and minis- } \\
\text { ter's son on horses go } \\
\text { hunting far away in a } \\
\text { jungle. They see a pool } \\
\text { and a Shiva temple } \\
\text { amidst beautiful } \\
\text { natural surroundings, } \\
\text { where they take a rest. }\end{array}$ \\
\hline
\end{tabular}

a Based on Riccardi, A Nepali Version of the Vetālapañcaviṃśati, 185-187.

b Based on Nepali printed version, author's name missing, Baitāla Pacissi, 106-108. 
TABLE 2 A comparison of the narratives in four different versions of the Vetala story (cont.)

\begin{tabular}{|c|c|c|c|c|}
\hline $\begin{array}{l}\text { Story } \\
\text { element }\end{array}$ & Nepali manuscript & $\begin{array}{l}\text { Nepali printed } \\
\text { version }\end{array}$ & $\begin{array}{l}\text { Oral version } 1 \\
\text { Ait Singh Gurung }\end{array}$ & $\begin{array}{l}\text { Oral version } 2 \\
\text { Dal Bahadur Gharti }\end{array}$ \\
\hline Scene 2 & $\begin{array}{l}\text { A young lady (a min- } \\
\text { ister's daughter) who } \\
\text { is a princess comes } \\
\text { to bathe accompa- } \\
\text { nied with her many } \\
\text { servants. Seeing this } \\
\text { young lady, the prince } \\
\text { falls in love. When } \\
\text { their glances meet, } \\
\text { they both were smit- } \\
\text { ten with love. }\end{array}$ & $\begin{array}{l}\text { The princess comes } \\
\text { up, bathes and wor- } \\
\text { ships the goddess } \\
\text { Bhavānī with full } \\
\text { devotion. }\end{array}$ & $\begin{array}{l}\text { A princess comes up } \\
\text { in a horse carriage, } \\
\text { stops it under the } \\
\text { cautāra } \bar{a}^{\mathrm{c}} \text { and goes to } \\
\text { the ghat to bathe. }\end{array}$ & $\begin{array}{l}\text { The princess, who } \\
\text { has never seen a man } \\
\text { or sunlight, regularly } \\
\text { comes there in a horse } \\
\text { carriage to bathe. }\end{array}$ \\
\hline Scene 3 & $\begin{array}{l}\text { The clever minister's } \\
\text { daughter takes a lotus } \\
\text { flower from her hair, } \\
\text { places it over her ear, } \\
\text { bites it with her teeth, } \\
\text { playfully crushes it } \\
\text { with her foot, places it } \\
\text { on her chest between } \\
\text { her breasts, says some- } \\
\text { thing to her friend and } \\
\text { climbs on an elephant } \\
\text { to return home. }\end{array}$ & $\begin{array}{l}\text { The eyes of the princes } \\
\text { and the prince meet } \\
\text { and they fall in love. }\end{array}$ & $\begin{array}{l}\text { After bathing, she } \\
\text { offers one flower to } \\
\text { the sky, one to the } \\
\text { earth, places one over } \\
\text { her ear, tears one } \\
\text { with her teeth and } \\
\text { throws it away, and } \\
\text { crushes a fifth one } \\
\text { under her foot, pats } \\
\text { her chest and departs. }\end{array}$ & $\begin{array}{l}\text { The two see each } \\
\text { other. The prince } \\
\text { wants to talk to } \\
\text { her, but she bathes } \\
\text { without uttering a } \\
\text { word. The princess } \\
\text { takes a lotus flower in } \\
\text { hand, looks the prince } \\
\text { in the eye, bites the } \\
\text { flower with her teeth, } \\
\text { places it over her } \\
\text { ear, presses it to her } \\
\text { bosom, puts it under } \\
\text { her foot and departs } \\
\text { for the palace in the } \\
\text { horse carriage. }\end{array}$ \\
\hline
\end{tabular}

Scene 4 The minister's daughter was so overcome by love that she becomes thinner day by day like the full moon.

c A tree-shaded platform along a road for travellers to rest on. 
TABLE 2 A comparison of the narratives in four different versions of the Vetala story (cont.)

\begin{tabular}{|c|c|c|c|c|}
\hline $\begin{array}{l}\text { Story } \\
\text { element }\end{array}$ & Nepali manuscript & $\begin{array}{l}\text { Nepali printed } \\
\text { version }\end{array}$ & $\begin{array}{l}\text { Oral version } 1 \\
\text { Ait Singh Gurung }\end{array}$ & $\begin{array}{l}\text { Oral version } 2 \\
\text { Dal Bahadur Gharti }\end{array}$ \\
\hline ene 5 & $\begin{array}{l}\text { The Prince was also } \\
\text { greatly overcome } \\
\text { by love and loses all } \\
\text { desires for food and } \\
\text { pleasure. He decides } \\
\text { that if he does not } \\
\text { find her he will die. } \\
\text { The minister's son } \\
\text { comes to the prince } \\
\text { and says it is not } \\
\text { right to lose his heart } \\
\text { and he should not } \\
\text { worry about her } \\
\text { whereabouts since } \\
\text { he understood all of }\end{array}$ & $\begin{array}{l}\text { The prince loses } \\
\text { consciousness and } \\
\text { the minister asks him } \\
\text { what kind of trick } \\
\text { the beautiful lady } \\
\text { has played. }\end{array}$ & $\begin{array}{l}\text { The agitated king } \\
\text { becomes emaciated. } \\
\text { He summons his } \\
\text { country's wise men } \\
\text { and reveals the matter } \\
\text { to them. When they } \\
\text { fail to diagnose his } \\
\text { malady, he suspects } \\
\text { the minister and } \\
\text { dismisses him. Later, } \\
\text { when the wise men } \\
\text { opine that only the } \\
\text { minister can solve the } \\
\text { problem, he calls the } \\
\text { minister back. }\end{array}$ & $\begin{array}{l}\text { The disappointed } \\
\text { prince comes to his } \\
\text { friend and tells him } \\
\text { about the beautiful } \\
\text { girl. The minister's } \\
\text { son takes him home, } \\
\text { but the latter suffers } \\
\text { from depression. The } \\
\text { minister's son assures } \\
\text { the prince that he will } \\
\text { help him to search for } \\
\text { his love. }\end{array}$ \\
\hline
\end{tabular}

Scene 6 The minister's son interprets the signs of the princess. The prince requests the minister to take him there. Both mount horses and on the pretext of going hunting, set out to find the minister's daughter.

Scene 7 The minister's son's explanation of the gestures:

- Placing the lotus over her ear: There is a king by the name of Karṇotpala in Kalinga.

- Biting the lotus leaf with her teeth: the king has a minister named Dantaghātaka, who destroys his enemies.
The minister then explains the series of signs. Then the prince becomes unconscious. The prince requests him to arrange his wedding with that lady and they leave together.

The minister explains the gestures:

- Putting a flower on her head: she is the best

- Taking the lotus and putting it over her ear: I am from Karnapura and the daughter of Dantaghāta.

- Placing it on her chest between her breasts: I am unmarried.
The two arrange food and money for their trip and go to the princess's city on horses.
The minister explains the gestures:

- She offered the first flower to the sky,

- The second to the earth goddess.

- Putting a flower over her ear: her father is Kanpur's king.

- Biting it with her teeth: her mother is Queen Dantavati.
On the way, the prince asks the meaning of the gestures. The minister's son explains:

- Dantapur is my country.

- Karnavat is my father.

- Padmāvatīis my name.

- Pressing the flower to her bosom: a signal that we will meet each other again. 
TABLE 2 A comparison of the narratives in four different versions of the Vetala story (cont.)

\begin{tabular}{lll}
\hline $\begin{array}{l}\text { Story } \\
\text { element }\end{array}$ & Nepali manuscript & $\begin{array}{l}\text { Nepali printed } \\
\text { version }\end{array}$ \\
\hline & $-\begin{array}{l}\text { Placing it under } \\
\text { her foot: her name } \\
\text { is Padmāvatī. }\end{array}$ & $\begin{array}{l}\text { Pressing the flower } \\
\text { name is Padmāvatī. }\end{array}$ \\
- & $\begin{array}{l}\text { Pressing it to } \\
\text { her chest: she } \\
\text { loved you. } \\
\text { Turning her face } \\
\text { and looking at the } \\
\text { prince: summon- } \\
\text { ing you to her. }\end{array}$
\end{tabular}

Scene 6 The prince and minister's son visit the house of Padmāvatì's nurse. They send her as a messenger to Padmāvatī.

Scene 7 The princess is happy to learn this from the nurse, but she pretends to be angry. Applying camphor and sandalwood paste to both hands, she draws ten lines down the old woman's cheeks and sends her off. The women reaches the house weeping miserably. The prince is bewildered. The minister's son tells the prince that the camphor and sandalwood paste were applied to cool the heat of his passion and to wait for ten moonlit nights.

\author{
Oral version 1 \\ Ait Singh Gurung
}

Oral version 2

Dal Bahadur Gharti

The minister and the The king and minister

prince reach the house visit the house of of a garland supplier Padmāvatī's wet lady. They send her to nurse. Offering her tell the princess that the earlier man whom 5 oo rupees, they send her to Padmāvatī to she met at the pool has arrived. tell her that the earlier man has arrived.

The prince and minister's son ask the way to the country of Dantapur and ask if its king has a daughter. They visit the princess's wet nurse. The wet nurse brings the message that they should enter the quarters later that night. She is rewarded with 500 rupees.
The princess applies sandal to both hands and marks the garland supplier lady's cheeks. The minister is happy to know this and tells the prince to wait ten moonlit nights.
The princess scratches five lines down the wet nurse's cheek and dismisses her. The minister interprets this as a signal to wait for five days. 
TABLE 2 A comparison of the narratives in four different versions of the Vetala story (cont.)

\begin{tabular}{lllll}
\hline Story & Nepali manuscript & Nepali printed & Oral version 1 & Oral version 2 \\
element & version & Ait Singh Gurung & Dal Bahadur Gharti \\
\hline
\end{tabular}

$\begin{aligned} & \text { Scene } 8 \quad \text { The next time she } \\ & \text { again feigns anger, and } \\ & \text { draws three lines on } \\ & \text { her chest with curds. } \\ & \text { They let her out. The } \\ & \text { prince despairs and } \\ & \text { faints. The minister's } \\ & \text { son privately explains } \\ & \text { to the prince that the } \\ & \text { princess is having here } \\ & \text { menstrual period, so } \\ & \text { he should wait three } \\ & \text { more days. }\end{aligned}$

Scene 9 The nurse visits Padmāvatī after three days. Just then a mad elephant breaks its restraining rope, shatters the wall and escapes. Princess ties up the nurse with the elephant's rope, drops her from a window and sends her down the path through the broken wall made by the elephant.

Scene 9 The minister's son suggests that the prince visit her by going through the hole in the broken wall and by grasping the rope. The prince reaches the princess. She conceals him during the day and enjoys the night together with him. They spend some days this way.
The next time the

princess applies saffron to her thumbs and marks her cheeks thrice. The minister privately explains to the prince that the princess is having here menstrual period, so he should wait three more days.

The lady garland supplier visits Padmāvatī after three days. She sends her out through The next time, she throws the wet nurse out a window in the east.
The minister sends the prince to Padmāvatī through the door in the west.
The princess ${ }^{d}$ brings a ladder. The couple live as a royal couple for a month.
The prince visits the princess in the evening and spends some days with her. 
TABLE 2 A comparison of the narratives in four different versions of the Vetala story "How the Prince Obtained a Wife" (cont.)

\begin{tabular}{|c|c|c|c|c|}
\hline $\begin{array}{l}\text { Story } \\
\text { element }\end{array}$ & Nepali manuscript & $\begin{array}{l}\text { Nepali printed } \\
\text { version }\end{array}$ & $\begin{array}{l}\text { Oral version } 1 \\
\text { Ait Singh Gurung }\end{array}$ & $\begin{array}{l}\text { Oral version } 2 \\
\text { Dal Bahadur Gharti }\end{array}$ \\
\hline Scene 10 & $\begin{array}{l}\text { The prince remem- } \\
\text { bers his friend and } \\
\text { shares his feeling with } \\
\text { the Padmāvatī. She } \\
\text { sends him off with } \\
\text { some food she has } \\
\text { prepared and requests } \\
\text { that he return. }\end{array}$ & $\begin{array}{l}\text { The princess sends } \\
\text { poisoned sweetmeats } \\
\text { with him. }\end{array}$ & $\begin{array}{l}\text { The king remembers } \\
\text { his minister and horse. } \\
\text { The princess sends } \\
\text { him off with four } \\
\text { poisoned sweetmeats. }\end{array}$ & $\begin{array}{l}\text { The minister's son } \\
\text { thinks he should } \\
\text { get the prince out } \\
\text { of the palace and } \\
\text { return home. }\end{array}$ \\
\hline Scene 11 & $\begin{array}{l}\text { The minister knows } \\
\text { that a women who is } \\
\text { deeply in love with } \\
\text { her husband cannot } \\
\text { have another person } \\
\text { be dear to him. So the } \\
\text { food is poisoned. He } \\
\text { does not eat any of } \\
\text { the food and gives it } \\
\text { to a dog, which dies. } \\
\text { The prince gets very } \\
\text { angry. They decide } \\
\text { Padmāvatī should } \\
\text { be taken to their } \\
\text { own country. }\end{array}$ & $\begin{array}{l}\text { The minister guesses } \\
\text { that they are poisoned } \\
\text { and does not eat them, } \\
\text { but gives them to a } \\
\text { dog. The dog dies. }\end{array}$ & $\begin{array}{l}\text { The minister does not } \\
\text { eat them, but gives } \\
\text { them to a dog. The } \\
\text { dog dies. }\end{array}$ & \\
\hline Scene 12 & $\begin{array}{l}\text { King's son dies in } \\
\text { the country. } \\
\text { The minister's son sug- } \\
\text { gests that the prince } \\
\text { visit Padmāvatī, make } \\
\text { love to her and, when } \\
\text { she falls asleep, draw } \\
\text { the three lines of a } \\
\text { trident on her with } \\
\text { his fingernails and } \\
\text { come back with her } \\
\text { jewellery. }\end{array}$ & $\begin{array}{l}\text { The minister sug- } \\
\text { gests that the prince } \\
\text { visit Padmāvatī and } \\
\text { mark her thigh with } \\
\text { his finger nail, steal } \\
\text { her jewellery and } \\
\text { come back. }\end{array}$ & $\begin{array}{l}\text { The minister, hav- } \\
\text { ing suggested that } \\
\text { the king steal the } \\
\text { princess's diamond } \\
\text { necklace, makes a } \\
\text { trident and gives it } \\
\text { to him. }\end{array}$ & $\begin{array}{l}\text { The minister's son sug- } \\
\text { gests that the prince } \\
\text { mark the princess's } \\
\text { thigh with a hot iron } \\
\text { and come back to him. }\end{array}$ \\
\hline
\end{tabular}

d Ait Singh uses the word for queen instead of princess here and elsewhere. 
TABLE 2 A comparison of the narratives in four different versions of the Vetala story (cont.)

\begin{tabular}{|c|c|c|c|c|}
\hline $\begin{array}{l}\text { Story } \\
\text { element }\end{array}$ & Nepali manuscript & $\begin{array}{l}\text { Nepali printed } \\
\text { version }\end{array}$ & $\begin{array}{l}\text { Oral version } 1 \\
\text { Ait Singh Gurung }\end{array}$ & $\begin{array}{l}\text { Oral version } 2 \\
\text { Dal Bahadur Gharti }\end{array}$ \\
\hline Scene 13 & $\begin{array}{l}\text { The prince marks her } \\
\text { thigh and takes her } \\
\text { jewels and returns to } \\
\text { the minister's son. }\end{array}$ & $\begin{array}{l}\text { The news of the } \\
\text { theft in the palace } \\
\text { spreads in the city. }\end{array}$ & $\begin{array}{l}\text { The king marks the } \\
\text { princess's left thigh } \\
\text { with the trident and } \\
\text { takes the princess's } \\
\text { necklace. }\end{array}$ & $\begin{array}{l}\text { The prince does as } \\
\text { suggested. }\end{array}$ \\
\hline Scene 14 & $\begin{array}{l}\text { The minister's son } \\
\text { takes a trident and } \\
\text { puts on the clothes of } \\
\text { an ascetic and stays at } \\
\text { the burning grounds } \\
\text { near the forest. The } \\
\text { prince becomes his } \\
\text { disciple. }\end{array}$ & $\begin{array}{l}\text { The prince and minis- } \\
\text { ter become yogis. }\end{array}$ & $\begin{array}{l}\text { The king and minister } \\
\text { become yogis. }\end{array}$ & $\begin{array}{l}\text { The prince and minis- } \\
\text { ter's son become yogis. }\end{array}$ \\
\hline
\end{tabular}

An official announcement is made that whoever brings the princess's necklace back will be awarded half the kingdom.

Scene 15 As instructed by the minister's son, the prince goes to the market and displays the jewels in different places. The king's men see them and ask how he received them. He replies that only his guru knows the answer. The king's men go to meet the ascetic, but he tells them he will disclose the answer only in front of the king.
When the jewels are being sold, the messengers of the king recognise them and arrest the disciple. He says that only his guru knows about the jewels. A messenger is sent to the burning grounds to meet the minister in the guise of ascetic.
The minister remains at the burning ghats, and a shopkeeper takes the necklace and the king-yogi to the palace. 
TABLE 2 A comparison of the narratives in four different versions of the Vetala story (cont.)

\begin{tabular}{|c|c|c|c|c|}
\hline $\begin{array}{l}\text { Story } \\
\text { element }\end{array}$ & Nepali manuscript & $\begin{array}{l}\text { Nepali printed } \\
\text { version }\end{array}$ & $\begin{array}{l}\text { Oral version } 1 \\
\text { Ait Singh Gurung }\end{array}$ & $\begin{array}{l}\text { Oral version } 2 \\
\text { Dal Bahadur Gharti }\end{array}$ \\
\hline Scene 16 & $\begin{array}{l}\text { The king goes to the } \\
\text { burning grounds and } \\
\text { asks the ascetic. The } \\
\text { ascetic replies: "The } \\
\text { daughter of the min- } \\
\text { ister, Dantaghātaka, is } \\
\text { in reality a demoness. } \\
\text { Every night she prowls } \\
\text { about naked and } \\
\text { devours a child. Last } \\
\text { night she ate a child } \\
\text { with royal marks and } \\
\text { brought it to the burn- } \\
\text { ing grounds. I angrily } \\
\text { struck her left thigh } \\
\text { with my trident and, } \\
\text { putting her under my } \\
\text { power, took her jewels. } \\
\text { If she is allowed to } \\
\text { remain in the city, no } \\
\text { child will remain safe." }\end{array}$ & $\begin{array}{l}\text { The minister in the } \\
\text { guise of an ascetic } \\
\text { explains to the mes- } \\
\text { senger: "Last night } \\
\text { there was a wanton } \\
\text { demoness. I hit her } \\
\text { with a trident on her } \\
\text { thigh. She ran away } \\
\text { and left her jewels } \\
\text { behind. You need find } \\
\text { the thigh to know } \\
\text { whose jewels are } \\
\text { these." }\end{array}$ & $\begin{array}{l}\text { The yogi says that one } \\
\text { of the many witches in } \\
\text { the kingdom gave it to } \\
\text { him. She has the mark } \\
\text { of a trident on her left } \\
\text { thigh. }\end{array}$ & $\begin{array}{l}\text { The yogis announce } \\
\text { that there are many } \\
\text { witches/magicians in } \\
\text { the kingdom, one of } \\
\text { whom came to them } \\
\text { at night. They hit her } \\
\text { with iron tongs, so she } \\
\text { doubtless has a mark } \\
\text { on her body. }\end{array}$ \\
\hline Scene 17 & $\begin{array}{l}\text { The king is overcome } \\
\text { with anger and, griev- } \\
\text { ing for his son, sends } \\
\text { a trusted woman to } \\
\text { examine Padmāvatīs } \\
\text { body. They see the } \\
\text { sign on her body and } \\
\text { consider her to be a } \\
\text { demoness. }\end{array}$ & $\begin{array}{l}\text { The messenger } \\
\text { delivers this mes- } \\
\text { sage to the king. The } \\
\text { message is proven } \\
\text { true. The ascetic is } \\
\text { asked what to do for a } \\
\text { punishment. }\end{array}$ & $\begin{array}{l}\text { The king orders all } \\
\text { women to take off } \\
\text { their clothes. Finally, } \\
\text { his own daughter } \\
\text { comes out. He orders } \\
\text { the witch to be } \\
\text { hanged. Then the yogi } \\
\text { suggests that if there } \\
\text { is a witch in a palace, } \\
\text { she should be exiled. }\end{array}$ & $\begin{array}{l}\text { Villagers spread a } \\
\text { rumour that the witch } \\
\text { will die. The king, } \\
\text { suspicious, checks } \\
\text { his wives. He finds a } \\
\text { wound on his daugh- } \\
\text { ter's body and orders } \\
\text { all his ministers to } \\
\text { banish the princess. }\end{array}$ \\
\hline Scene 18 & $\begin{array}{l}\text { The ascetic suggests } \\
\text { that since women } \\
\text { are not to be killed, } \\
\text { Padmāvatī should } \\
\text { be driven out of the } \\
\text { country. }\end{array}$ & $\begin{array}{l}\text { The ascetic suggests } \\
\text { that according to the } \\
\text { religious scriptures, } \\
\text { Brahmins, children } \\
\text { and women are not } \\
\text { to be killed but are to } \\
\text { be driven out of the } \\
\text { country. Padmāvatī, } \\
\text { the demoness, is } \\
\text { driven out of the } \\
\text { country. }\end{array}$ & & \\
\hline
\end{tabular}


TABLE 2 A comparison of the narratives in four different versions of the Vetala story (cont.)

\begin{tabular}{|c|c|c|c|c|}
\hline $\begin{array}{l}\text { Story } \\
\text { element }\end{array}$ & Nepali manuscript & $\begin{array}{l}\text { Nepali printed } \\
\text { version }\end{array}$ & $\begin{array}{l}\text { Oral version } 1 \\
\text { Ait Singh Gurung }\end{array}$ & $\begin{array}{l}\text { Oral version } 2 \\
\text { Dal Bahadur Gharti }\end{array}$ \\
\hline Scene 19 & $\begin{array}{l}\text { Alone, Padmāvatī wan- } \\
\text { ders into the forest. } \\
\text { The prince, dressed } \\
\text { in his own attire, } \\
\text { goes to the forest. He } \\
\text { explains everything to } \\
\text { Padmāvatī and takes } \\
\text { her to Varanasi. They } \\
\text { reach there and have } \\
\text { manifold pleasure } \\
\text { together. }\end{array}$ & $\begin{array}{l}\text { The prince sets out } \\
\text { on a horse and takes } \\
\text { Padmāvatī with him } \\
\text { to his city. They are } \\
\text { married and the king } \\
\text { enjoys his life with } \\
\text { Padmāvatī. }\end{array}$ & $\begin{array}{l}\text { The princess is set on } \\
\text { an elephant, makes } \\
\text { three rounds of the } \\
\text { city and is driven out. } \\
\text { The king and minister } \\
\text { also go away. They } \\
\text { change their clothes } \\
\text { and take the princess } \\
\text { home to form a royal } \\
\text { couple. }\end{array}$ & $\begin{array}{l}\text { The prince and prin- } \\
\text { cess marry without a } \\
\text { formal agreement or } \\
\text { dowry and live in a } \\
\text { palace. }\end{array}$ \\
\hline Scene 20 & $\begin{array}{l}\text { Padmāvatī's father } \\
\text { Dantaghāțaka is no } \\
\text { longer trusted by the } \\
\text { king and so is exiled. } \\
\text { He dies from grief over } \\
\text { being separated from } \\
\text { his beloved daughter. } \\
\text { His wife follows him } \\
\text { into the fire. }\end{array}$ & $\begin{array}{l}\text { Padmāvatī's father } \\
\text { Dantaghāta dies from } \\
\text { the grief over his } \\
\text { daughter. }\end{array}$ & & \\
\hline Riddle & $\begin{array}{l}\text { The minister and his } \\
\text { wife died because of } \\
\text { the grief over their } \\
\text { daughter. Upon whom } \\
\text { does the guilt attach } \\
\text { for their death? }\end{array}$ & $\begin{array}{l}\text { Upon whom does the } \\
\text { guilt attach? }\end{array}$ & & $\begin{array}{l}\text { Who became a king } \\
\text { and who became a } \\
\text { yogi? }\end{array}$ \\
\hline
\end{tabular}


TABLE 3 A comparison of the narratives in three different versions of the Vetala story "The Story of the Mixed Relationships"

\begin{tabular}{|c|c|c|c|}
\hline $\begin{array}{l}\text { Story } \\
\text { element }\end{array}$ & Nepali manuscript ${ }^{a}$ & Nepali printed version ${ }^{b}$ & $\begin{array}{l}\text { Oral version } \\
\text { Gajabal Thapa }\end{array}$ \\
\hline $\begin{array}{l}\text { City and } \\
\text { protagonists }\end{array}$ & $\begin{array}{l}\text { Dharmasimha (King of } \\
\text { Dharmapura) } \\
\text { Chandravati (wife of } \\
\text { Dharmasimha) } \\
\text { Lavaṇyavatī (princess, } \\
\text { daughter of Dharmasimha) } \\
\text { Chandasinha (a Kṣatriy) } \\
\text { Siṃhaparākrama } \\
\text { (Chandasinha's son) } \\
\text { (King Vikramasena and the } \\
\text { Vetala appear at the end.) }\end{array}$ & $\begin{array}{l}\text { Jaising (King) } \\
\text { Chandravati (Queen) } \\
\text { Lavanyavatī (princess) } \\
\text { Saheb (head, father) } \\
\text { Satyeshvar (son of Saheb) } \\
\text { (King Vikramaditya and the } \\
\text { Vetala appear at the end.) }\end{array}$ & $\begin{array}{l}\text { A king } \\
\text { The king's queen } \\
\text { A princess } \\
\text { Another king } \\
\text { A prince } \\
\text { (King Vikramaditya and the } \\
\text { Vetala are not mentioned.) }\end{array}$ \\
\hline
\end{tabular}

Scene 1 Dharmapura was attacked by king Dharmashimha's ememies. Dharmasimha's kinsmen and ministers went over to the enemy and he

One day an enemy attacked from every side. The king was killed in the battle and the queen escaped with Lavanyavatī. was defeated. The king took his queen Chandravati and daughter Lavanyavati and fled from there to a forest.

Scene 2 They came to a village of Bhillas who were dressed in tiger skin. The Bhillas attacked to steal the jewels of the king's crown and killed him.

Scene 3 After seeing the king killed before them in the battle with Bhillas, the queen and princess fled from there and reached a forest.

Scene 4 Chandasinha, a Kṣatriya accompanied with his son Siṃhaparākrama, entered the forest to hunt.
A king came to some other king's country and fought a big battle. The king and his armed forces were killed. The queen and the princess managed to escape and reached a forest.

They reached the middle of a forest and lived there.

A king from another country and his son came to that forest to go hunting.
Satyeshwar in some other country. One day he went hunting accompanied by Saheb, his father.

a Based on Riccardi, A Nepali Version of the Vetālapañcavimśati, 185-187.

b Based on a Nepali printed version, author's name missing, Baitāla Pacīsī, 106-108. 
TABLE 3 A comparison of the narratives in three different versions of the Vetala story (cont.)

$\begin{array}{llll}\begin{array}{l}\text { Story } \\ \text { element }\end{array} & \text { Nepali manuscript } & \text { Nepali printed version } & \begin{array}{l}\text { Oral version } \\ \text { Gajabal Thapa }\end{array} \\ & & \end{array}$

\begin{tabular}{|c|c|c|c|}
\hline Scene 5 & $\begin{array}{l}\text { On the road, Chandansinha } \\
\text { saw the footprints of women } \\
\text { with royal marks. One pair } \\
\text { was small and one pair was } \\
\text { large. }\end{array}$ & $\begin{array}{l}\text { They recognised the } \\
\text { footprints of two women. }\end{array}$ & $\begin{array}{l}\text { The king and his son passed } \\
\text { the same way that the queen } \\
\text { and princess had passed } \\
\text { through. }\end{array}$ \\
\hline Scene 6 & $\begin{array}{l}\text { Candansinha happily said to } \\
\text { his son Sinhaparikrama: "My } \\
\text { son, look, two women have } \\
\text { entered the forest. There is } \\
\text { the mark of royalty on their } \\
\text { feet. We are Kṣatriyas. If we } \\
\text { obtain such wives, we shall } \\
\text { also obtain the kingdom }\end{array}$ & $\begin{array}{l}\text { The King thought and said: } \\
\text { "The one with bigger feet will } \\
\text { be my wife and the beautiful } \\
\text { lady with small feet will } \\
\text { be yours." }\end{array}$ & $\begin{array}{l}\text { The father and son had a dis- } \\
\text { cussion. They concluded that } \\
\text { the footsteps are of women. } \\
\text { The father decided that he } \\
\text { will take the lady with bigger } \\
\text { feet and promised that the } \\
\text { lady with smaller feet will be } \\
\text { for his son. }\end{array}$ \\
\hline
\end{tabular}

indicated by their royal marks. If we meet them, the one with large feet shall be my wife and the one with small feet shall be yours."

Scene $7 \quad$ They finally came to the lake and met the mother and daughter.

They reached the lake and met them.

The lady with the small feet turned out to be an elderly woman; the daughter Lavanyavatī had large feet.

Scene 8

Scene 9 small feet, her mother.

The one with the large feet turned out to be the daughter and the one with the Remembering the agreement they had made previously, the father made the daughter his wife and the son married her mother.

$$
\begin{aligned}
& \text { The father and the son } \\
& \text { returned home with their } \\
& \text { wives. Since the king of } \\
& \text { the clan had died, they } \\
& \text { inherited the kingdom } \\
& \text { indicated by their marks and } \\
& \text { enjoyed happiness. }
\end{aligned}
$$

The mother became wife of the father and the daughter, of the son.
They reached the midst of the forest, and reached the place where the queen and princess were sitting.

According to the agreement, the father took the lady with large feet and the son, the one with small feet. The woman with small feet was the mother, and the woman with large feet was the daughter. 
TABLE 3 A comparison of the narratives in three different versions of the Vetala story (cont.)

\begin{tabular}{llll}
$\begin{array}{l}\text { Story } \\
\text { element }\end{array}$ & Nepali manuscript & Nepali printed version & $\begin{array}{l}\text { Oral version } \\
\text { Gajabal Thapa }\end{array}$ \\
\hline Scene 10 & $\begin{array}{l}\text { As time passed the mother } \\
\text { and daughter gave birth to } \\
\text { many children. }\end{array}$ & & \\
Riddle & $\begin{array}{l}\text { In what relation are the } \\
\text { children born into the line } \\
\text { of these two people? }\end{array}$ & $\begin{array}{l}\text { Please describe the relation } \\
\text { of the children born to them. }\end{array}$ & $\begin{array}{l}\text { What is the relation between } \\
\text { those two? Please explain; }\end{array}$ \\
& & & I do not understand.
\end{tabular}

There are several new elements introduced in Ait Singh's and Dal Bahadur's versions. The first new element in Ait Singh's version is the mention of a fair taking place on somvare aũs $\bar{t}^{52}$ which sets the scene for the meeting between Padmāvatī and the prince. In the standard versions, the prince goes hunting, reaches a temple and comes across the princess in the jungle. This is also found in Dal Bahadur's version. Both new versions refer to the princess as maiy ã, a term used in those days either for a king's daughter or as an honorific term for an unmarried girl. Ait Singh recounts Padmāvatī engaging in an act of worship conforming to the Hindu tradition, offering a flower to the sun and another to mother earth, before communicating with the king by means of signals. In the original versions and Dal Bahadur's version, she does not offer a flower to any god before gesturing to the prince. What is particularly striking in Ait Singh's version is that the prince of the original story has become a king portrayed in a much less flattering light than the original prince. Indeed, since Ait Singh was a prisoner of war and a victim of political manoeuvring, he may have been using his recording to make a veiled statement about his own situation. For example, the king suspects that his lovesickness is due to his own minister's sorcery, which is aimed at killing him and taking over the kingdom. Indeed, the Pows in Germany interpreted the war as a battle of several kings, and further acknowledged that when the war began, they became aware of

$5^{2}$ Somvare aũsi is the day of a new moon that falls on a Monday. Such a convergence is considered very auspicious in Hindu religious texts. Taking a bath on that day at a riverbank without speaking a word is believed to earn one great merit; likewise, performing rituals for deceased ancestors, worshipping Vishnu, and making one hundred circumambulations of a peepal tree are all traditional forms of worship in the Hindu tradition. On the day of somvare aũsī many sites along riverbanks serve pilgrims, or ghats, like the one mentioned in the story, are the sites of fairs $($ melā $)$. 
several kings whom they had not heard of earlier. ${ }^{53}$ On the other hand, Ait Singh's version displays much more modesty when describing the lovemaking between the king and Padmāvatī. The one month of secret romance between the prince and Padmāvatì at the palace becomes "rājā rānī bhai rahe" (they lived as king and queen), with the erotic scenes found in the Sanskrit and Hindi versions no longer appearing. For instance, there is no mention of the princess requesting the prince to remain patient for three nights during her menstruation. Dal Bahadur, for his part, does justice to this part of the story, however briefly, by mentioning the prince's stay of a few days in the palace with the princess. In the earlier versions, Padmāvatî's father learns the truth about his daughter and banishes her secretly, whereas Ait Singh has all the women of the city examined for a tell-tale mark on their bodies in the search for the witch, before Padmāvatì is examined. Once discovered for who she is, Padmāvatī is seated on an elephant and after making three rounds of the city, is publicly expelled. Both Ait Singh and Dal Bahadur give the story a happy ending by uniting the two lovers with hints that they had a long married life. There is no vestige of the sad outcome in the earlier versions (including the above representative Hindi version) of Padmāvatīs parents dying of grief at having lost their daughter. The endings of Ait Singh's and Dal Bahadur's stories may bespeak a positive attitude towards their own lives and futures. Perhaps they had someone back in Nepal whom they were looking forward to reunite with. It is also interesting to see how, at the end of the story, Dal Bahadur describes the marriage as being finalised without any formal agreement or dowry. This may indicate his view of the expensive and complicated wedding process in South Asia. Dal Bahadur's down-to-earth views are also reflected in his having the prince and minister's son go home to fetch some money and food for their trip. He thus inserts elements of everyday reality into his version of the fable. Further, he does not have the prince steal any jewellery from the palace. For him, it was enough that the princess is accused of being a witch to cause her to be expelled, a perfect mirroring of the superstitious nature of society of his own time. It is also interesting to see that both pows rewarded the wet nurse with five hundred rupees, which may signal the importance they attached to remuneration in a soldier's life. What does not change in the story, however, is the narrative's main thread: A prince and Padmāvatī see each other in a jungle, Padmāvatī gives some signals, the prince goes to find her with his friend, exposes her as a witch and makes her father abandon her, and finally the prince marries her. It is a thread that runs through the beads of the storytellers' own imagination and memory. 
In comparison to the tale recounted by Ait Singh and Dal Bahadur, the story of Gajabal is shorter. One might ask why Gajabal chose this particular VP story and not another. There are several elements in the story that might have influenced his decision: war, victory and loss, the father dying, the mother and daughter escaping and residing in a forest as captives, or the mother and daughter being taken away by people they did not know from the middle of a forest. Any of these elements may have reminded him of his own circumstances, his own and fellow pows experiences of war, or the Pow camp in a German forest.

The documentation connected to the recordings reveals that the texts were first memorized, then written down by the storyteller or was dictated to someone else, and finally copied, transliterated and translated. Once a story was approved by the committee at the Phonographic Commission responsible for recording South Asian Pows, the recording could go ahead. The recordings of Ait Singh, Dal Bahadur and Gajabal have been preserved in the Sound Archive at Berlin's Humboldt University. The handwritten versions, probably in the Pows' own handwriting, and a separate copy in better and clean handwriting are preserved in the Heinrich Lüders Collection. ${ }^{54}$ Some parts of these texts are written in Devanagari, transliterated into Roman script, and translated into German.

In addition to small differences in their contents, a major difference in the recordings from the stories found in the Sanskrit and Nepali manuscripts or published versions is the lack of a riddle at the end of each story. To be sure, Dal Bahadur and Gajabal did mention a riddle, but separately. They may have been confused as to whether the riddle was actually part of the story. In any case the fact that they added a separate riddle shows that they did know, if not the exact riddle, the format of the original vp stories. Dal Bahadur asks: "Who became a king and who a yogi?" In Nepali, the word yogi also means a beggar. One might conjecture that Dal Bahadur's thoughts were on the ongoing war and its possible outcome; he was not sure who would win and who would lose. Gajabal also concludes his story by asking a question, thus following the original riddle format. He has, however, forgotten that in the original story, the riddle is asked by the Vetala to King Vikramaditya, and ends his recording in the first person: "I do not understand". This suggests that he has made himself part of the narration.

54 One page of Ait Singh's handwritten version of the story is preserved in NL Lüders Nr. 4: Bd. 6, 76; versions written by someone else are in NL Lüders Nr. 4: Bd. 6, 41-42 and 48-49. Dal Bahadur's handwritten version is found in NL Lüders Nr. 4: Bd. 3, 32-33. Gajabal's handwritten version is in NL Lüders Nr. 4: Bd. 3, 11(a)-11(b). 
The impression that these recordings leave is that their reciters had a fairly good command of Nepali. A hundred years ago, ethnic communities in Nepal spoke their own mother tongues; for them Nepali was a lingua franca and the language of the Khas, that is, people of Indo-Aryan origin in present day Nepal. We can thus assume that Ait Singh's mother tongue was Gurung, and Dal Bahadur's and Gajabal's was Magar. In comparison to Ait Singh's quite Sanskrit-like Nepali, the Nepali of Dal Bahadur shows more Urdu influences. Gajabal's short narrative presents an example of the standardized Nepali language of the period. There are, however, also notable Hindi/Urdu influences, such as the frequent use of Hindi/Urdu words and suffixes, which reflects the time these men spent in India and their long exposure to Hindi/Urdu speakers and Hindi reading material. Sometimes, for instance, they confuse the Hindi dative-accusative postposition for the Nepali one, ${ }^{55}$ and they stumble over certain vocabulary terms, such as cognates having different meanings in Hindi and Nepali. ${ }^{56}$ Often, too, they do not pay attention to gender or number agreement between subject and verb.

\section{Conclusion}

Having undertaken this analysis, we return once again to the central matter at hand: the fluidity of textual traditions. As has been suggested by Sathaye, ${ }^{57}$ fluid textual traditions like that of the vp belonged to the distinct Sanskrit culture that thrived in medieval and early modern India. This article has shown that that tradition extended into the twentieth century, a tradition still alive in vernacular languages and among the general public. Not every text succeeded in being a part of that tradition. But the VP is one of the rare texts that thrived and travelled over a long period through both time and space. The examples of these Nepali versions of its stories show how the pre-modern Indian textual tradition was adopted in modern vernacular folklore. The three recordings of Nepali Pows illustrate the continuation of folklore from one era to another, from the Sanskrit public culture of the medieval period to the modern public tradition of storytelling. The stories, in their new versions, are an excellent example of a text passing from one language, era and continent to another.

55 As in the following two examples of dative-accusative postposition in Hindi: मन्त्रीको निन्द्रा परी गयो (The minister fell asleep)। राजाको सपनामा देखे (Then he saw the king in a dream).

$5^{6} \quad$ For example, in Hindi the verb mārnā means both "to beat" and "to kill," whereas in Nepali it means only the latter. Ait Singh uses this verb in the former meaning.

Sathaye, "The Scribal Life of Folktales," 14. 
They also document how texts are influenced by external circumstances and the personal experiences of the reciter or scribe.

The stories recited by the three pows may have been ones they knew the German Indologist Lüders was familiar with and thus would have no qualms about recording. Lüders himself mentions the Gurkha Pows' recordings of the famous Vetālapañcavimśati stories that had been translated from the original Sanskrit into almost every Indian vernacular. ${ }^{58}$ Furthermore, we have evidence that Lüders had a command of Sanskrit and was familiar with the original vP stories, which suggests that a recording was only made after a story had been deemed suitable. Ait Singh, Dal Bahadur and Gajabal would not have felt much freedom of agency, and thus may have consciously decided not to test their limits. But it is also possible that the pows did not restrain themselves and recorded VP stories as they remembered them. Our storytellers may have struggled to recall the details of the folktales they were recounting. This may also be a reason for the deviations between the narratives of Ait Singh and Dal Bahadur.

I return to the questions raised at the outset: What can we learn from these recordings? Why did these individuals choose these particular stories and not others? Was the subject matter of the stories somehow related to their imprisonment in Germany? And what do the stories tell us about the history of Nepali literature? While these recordings are a small piece of evidence about that history, nonetheless they are significant. Gurkhas were major consumers of popular Nepali literature published in India. The stories told by these three Pows were not the ordinary local folktales that everyone in their villages would have known; they are stories from a classic Sanskrit text that had been translated into Nepali and other vernaculars by elites, retold in many communities, published by Nepali entrepreneurs, and finally became reading material in Gurkha regiments. The vP travelled from the domain of elites to the broader public, including army recruits. The huge number of handwritten copies of the VP in Nepali manuscript archival holdings prove its popularity. The recordings of Ait Singh, Dal Bahadur and Gajabal are testimony to how the vP travelled across the continent, through languages and communities. Examining those century-old recordings has also shown how the process of a text's transmission, whether oral, handwritten or printed, can lead to new oral, handwritten, printed and even recorded versions.

The work of the Royal Prussian Phonographic Commission was not designed to spread the output of the Pows' to a wider German audience or to the Pows' homeland; it was undertaken for its linguistic value alone. Indeed,

58 Lüders, "Die Gurkas," in Unter fremden Völkern: eine neue Völkerkunde, ed. Wilhelm Doegen (Berlin: Stollberg, 1925), 135. 
the recordings have both linguistic and literary value, encapsulating as they do a slice of the history not only of the language of Nepal, but also its literature. The recordings produced by the commission are therefore valuable, whether in historical, linguistic, literary or simple human terms. They also show how printed or written texts can live on in an oral form. In this case their contents were carried from Asia to far-off Europe, where they were retold, captured on a recording cylinder, written down and translated.

While the VP was a text originally fashioned by the Brahmanical elite, over time it found its way to a more general audience, including the three Nepalis featured in this article. The Nepali Brahmin publishers in Varanasi, well aware of the Brahmanical text tradition, had such texts translated into Nepali to print and sell to Gurkha soldiers. Textual transmission of this type served to develop a bond between the two social groups. Moreover, the selection of VP stories by the colonial forces for translation, textbook publication and language learning played an additional vital role in popularizing these stories, as the recitations in a Pow camp prove without a doubt. The stories recorded by Ait Singh, Dal Bahadur and Gajabal are, as noted, condensed and quite different from the originals. The changes they introduce into the VP text are not of a religious or didactic nature, but rather add purely personal or social touches. They doubtless felt free to make changes to the text as they had read or heard it back home. In fact, despite clearly being retellings of VP stories, it is only with some difficulty that they can be recognized as such. These recordings are not only an offshoot of the emerging print culture in South Asia, they are also an offshoot of colonization: the VP was not only a popular Sanskrit text among Sanskritists, it was also translated at Fort William College in Calcutta and later adopted by the British army as a reading text for its regiments. This allowed its popularity to rise among soldiers, something cashed in on by publishing houses. Were it not for the colonial authority and the print entrepreneurs of that time, it is possible that we would not be discussing the above three versions of VP stories today.

\section{Appendix $1^{59}$}

\section{The First Part of the Story Told by Ait Singh Gurung}

Archive No. PK 246, Sound Archive, Humboldt University, Berlin. Recorded at the POW camp in Wünsdorf, Germany, on 29 May 1916 at 12:45. Duration: o2:32.

59 Transcription and translation by the author. The Roman and Devanagari versions of the text as found in the archive are transcriptions, that is, attempts to render the text as it was actually spoken rather than with standardized Nepali spellings and transliterations. 
कोही एक जगामा एक राजा गरीब थियो । ऊ राजाको एक मन्त्री बडो भारी पशुभाषी बुझ्ने वाला थियो । एक (एक) ${ }^{60}$ जगामा बडो भारी मेला थियो । उस जगा (उस जगा) राजा र मन्त्री पनि गयाको थियो। उस दिनमा सोमवारे ओंसी परेको थियो। उस मेलाको नुआउने घाटमा एक चोतारा पनि थियो। उस चोताराको छहारीमा राजा र मन्न्ती बसेको थियो। मन्त्रीको निन्द्रा परी गयो र राजा बस्दे थियो। उस बखतमा कानपुरे राजाको छोरी मेंया बग्गीमाथि चढ़ी आएर उसे चोताराको मुनितिर बग्गीलाई थामेर नुआउने घाटमा गयो । नुआउनुलागे तब ऊ नुआइसके पछि पेला फूल आकाशमा चढायो दोम्रा फ़ल धरतीमा चढायो। तीसरा फूल आफ़ो कानमा लगायो। चोथा फ़ूल दाँतले च्याती फ्याले। पाँचौं फ़ूल पाउमा दबाइदिए र आफ़ो छातिमा धाप मारी बग्गीमाथि चढ़ी गए। तब राजाको (मन) मनमा सुर्ता परे (परे) । यो मैंयाले क्या काम गय्यो ? मेले बुझ्दु नसक्रे स्वभावले बिलकुल दुब्लो भयो। तब आफ़ो (राजा राज) राजमा भयाको पण्डितहरूलाई बोलाई हेराउनु लागे। कोही पण्डितले पनि यस्ते व्यथा हो भनी कसेले खार्नु सकेनन्। तब राजाको मनमा पाप मन फाँड़ लाग्यो कि मेरो मन्त्रीले हो मलाई मारी आफ़ राजा होला भनी यस्तो गरेको हो भनी मन्त्रीलाई निकाला गरिदियो। तब कोही दिनपछि पण्डितहरूले भन्नु लागे कि हजुरको मन्त्रीले सकुा त सक्ठा अरूले सक्रे छेन भनी हुकुम भयो (भयो) कि फेरि मेरो मन्त्रीलाई बोलाओ भनी हुकुम भयो । तब फेरि मन्त्रीलाई [आएर $]^{61}$ भन्नु लाग्यो, हजुरताई क्याको सुर्ता छ मसँग भन भनी मन्त्रीलाई [ले] ${ }^{62}$ राजासँग सोध्रु लागे ।

There (once) was a poor king somewhere. He had a minister who could well understand the language of animals. There was a big fair $($ melä) some place. The king and the minister also went there. It was Monday and a new moon day. At the fair's bathing ghat there was a cautārā. The king and the minister sat down in the shade of the cautārā. The minister fell asleep and the king [remained] sitting. During this time a girl, the daughter of the king of Kanpur, came up in a horse carriage, stopped it under the cautāra and went to the bathing ghat. She began to bathe, and when she had finished bathing, she offered a first flower to the sky and a second flower to the earth. She placed a third flower on her ear. She tore a fourth flower off with her teeth and threw it away. She crushed a fifth flower under her foot, patted her chest, got into the carriage and departed. The king became worried. "What has this girl done?" "It's in my nature not to understand, and so I've become completely emaciated." Then the king summoned his country's wise men and got them to look into the matter. Not a single

Thus one finds there forms such as rādza rather than rājā, and mandrī rather than mantrī. These transcriptions are not always the same for the same word. My own transcription inclines towards a transliteration of the standard word I feel the reciter's pronunciation most approximates. The Devanagari version, it should be noted, contains no punctuation marks, while the Roman version occasionally has full stops.

6o Words in brackets are those repeated or corrected by the reciter while speaking.

61 The archive's Devanagari text reads आएर ("came and"), although this cannot be heard in the recording. While it is not grammatically essential, it serves to improve clarity.

62 The archive's Devanagari text contains ले (transitive subject suffix), which is not heard in the recording but is the expected grammatical form. 
wise man — none of them—could diagnose the malady. The king then began to be assailed by the wayward thought that the minister wanted to kill him and assume the kingship - that he was the one who had staged the scene. Thinking this, he dismissed the minister. After a few days the wise men began to say, "If anyone can solve this problem, it's the minister; no one else will be able to." Hearing this, the king gave the order: "Call my minister back!" Then he began speaking to the minister again. The minister started (by) asking the king, "What are you worried about? Tell me."

\section{The Second Part of the Story Told by Ait Singh Gurung}

Archive No. PK 250, Sound Archive, Humboldt University, Berlin. Recorded at the POW camp in Wünsdorf, Germany, on 29 May 1916 at 14:25. Duration: 01:59 min.

तब राजाले भन्छन् कि मलाई केही पनि भयाको छेन। हामी एक दिन घुम्नु गयाको दिनमा एक मेयाँ आएर फूल चढायो। यो मतलब नबुझी म यो शोकले हो ।63

[हजुर बडा मान्छे भएर पनि यो बात को मततब पाएन । यो बातको वास्ते फिकर नगर्नू । म भन्दिमा। पेला फूल आकासमा चढायो। आकासताई चढायाको हो। दूसरा धर्ती मातालाई चढायाको हो। तीसरा आफ़ू कानमा लगाया। आफ़ु बाबुको नाम कानपुरी राजा हो। चोथा दाँतले टोकी फाले। आफ़ु आमाको नाम दन्त्तओती रानी हो । पाँचों पाउमा दबायो। आफ़ु नाम पद्मावती रानी हो भनिदिया। ₹ तब राजाको चित्त बुझी राजा दिनदिने बलियो हुँदे गयो। छातीमा धाप मारेको मर्द भया देखि आइज मेरो संगमा भन्येको हो। तब केही दिनपछि ऊ राजा र मन्त्री उसे कानपुरी राजाको छोरी मेयाँको धाई आमाको घरमा गई बास बसे। तब राजा मन्त्रीले भन्तु लागे कि म पाँच सो रुपिया दिन्छु । मेयाँसँग भन्नू उइलेको ऊ मान्छे आयाको छ भनी यति भन्तु भनी पठायो। मैयाँ थियो कि पशु भाग्ये बुझेवाला। मैयाँले पेले मालुम भएको थियो। तब मैयाँले क्या भनिस् भनी गालामा पाँच ओंता को डाम बसाली पठाई दियो। तब उ बुढी माउ भन्तु लागे कि तिमीहरु जाऊ मलाई मैयाले मार्यो भनी भन्दा । तब मन्त्रीले भने तिहाँ पाँच दिनसम्म बस्तु भनेको हो तिमीलाई मारेको होइन। फेरि दूसरा पालीमा पूर्व तर्फको इयालबाट फालिदियो। तब राजालाई मन्त्रीले भन्नु भने पुरब तरफको इयालबाट जानु भनी पठाए। तब रानीले भरेड् लाइ दिए । तब राजा रानी भई बसे । एक मेना दिनमा मन्त्रीले भन्नुतागे कागे कि एक मेना भयो मताई भुलि गयो। तब राजाको 64 सपनामा देखे । तब राजाले भन्नु लागे मेरो मन्त्री र घोडा कस्तो भयो भनि । तब मैयाँले कसार लडुको दानामा बिख हाली दिए। तब मन्त्रीलाई दियो । मन्त्रीले म खान्न भनी लिएन । पेले कुत्तालाई दे भनी कुत्तालाई दियाको बित्तिके कुत्ता मरिगयो ।]

65तब मन्त्रीले भन्नु लागे: मेयाँ को हीराको हार ल्याउनु पर्ता भनी एक त्रिशूल बनाई दियो। तब ऊ त्रिशूलको छाप बायाँ साप्रामा (छाप) लगाई दियो ₹ मेयाँको गताको हीराको हार लगी गयो । तब राजा मन्त्री जोगी भै गयो। तब राजाको छोरी मैयाँको हीराको हार हरायो भनी।(भनी) सारा दुनियाँमा हुकुम फिराई लियो कि मेरो छोरी मेयाँको हीराको हार जो सकसले ल्याउता ऊ

63 The following passage in italics is found in the written version but not on the recording.

64 In Hindi, को is the accusative postposition.

65 The recording picks the story up again from here. 
सकसलाई म आधा राज दिऊँला भनी हुकुम फिराई दियो । तब उसे राजा ₹ [को] 66 मन्त्रीले उस राजाको लेन देन गरने दोकानमा ऊ जोगी भयाको राजाले बुजाउनु गयो । मन्त्री (मन्त्री) मसान घाटमा बसे तब ऊ दोकानवालाले हीराको हार लगी राजाको दरबारमा दाखिल बनायो । तब राजाले दोकानवाला चोरीमा पकरे। मेले चोज्याको होइन (होइन) एक जोगीले बेच्चु आयाको थियो ऊ जोगीलाई ल्याउनु पठायो तब ...

The king replied, "It's nothing. One day when we were travelling, a girl came and offered flowers. I didn't understand the meaning of this, and that worries me." ${ }^{\prime 67}$

["Even though you are a great man, my lord, you have not found the meaning. Do not worry on account of this matter. I shall tell you. She offered the first flower to the sky. The second one she offered to the earth goddess. The third one she placed at her ear. Her father's name is King of Kanpur. ${ }^{68}$ The fourth one she tore off with her teeth and threw away. Her mother's name is Queen Dantavati. ${ }^{69}$ The fifth one she crushed under her foot. She gave [you] to understand that her name is Queen Padmāvati." ${ }^{\prime \prime 0}$ Then the king was satisfied and he recovered day by day. "Her gesture of patting her chest means that if you're a man, come with me." After some days the king and the minister visited the house of the wet nurse of the king of Kanpur's daughter. Then the king and the minister said, "I will give you five hundred rupees." He sent her (as a messenger) and asked her to tell the princess that the earlier man had arrived. The princess had the ability to know the fortunes of animals. The princess already knew this. Then the princess asked her what she meant. With five fingers she scratched five lines down her cheek and (angrily) sent her off. Then that old lady told them to go away, because the princess had beaten her. Then the minister said that (through that gesture) she was telling (them) to stay there five days; that she had not beaten (her). And the next time he threw (her) through a window in the east. Then the minister told the king that he should go (now), and sent him off (to enter the palace) through a window in the east. Then the queen ${ }^{71}$ brought a ladder (to assist his climb up to her). Then they lived as king and queen. After a month the minister thought (the king) had forgotten him. Then he saw the king in a dream. Then the king became worried about his minister (and) horse (and let his thoughts be known to the queen). Then the princess put poison in a kasār laddu. ${ }^{72}$ Then (the king) gave it to the minister. The minis-

66 [को] is only heard on the recording; it is not in the transcript.

67 The following passage in italics is found in the written version but not on the recording.

68 The meaning of $k \bar{a} n$ is "ear."

69 The meaning of danta is "tooth."

70 The meaning of pad is "foot."

71 The narrator uses the words queen and princess interchangeably, regardless of her actual status at that point in the story.

72 A Nepalese sweetmeat. 
ter did not accept it, saying, "I won't eat it." He told him to give it to a dog, and as soon as the dog ate it, it died. $]^{73}$

Then the minister said, "We need to get the princess's diamond necklace." Then he made a trishül. ${ }^{74}$ Then he made a mark with the trishül on her left thigh and took the princess's diamond necklace. Then the king and the minister became yogis. Then the king's daughter's diamond necklace was discovered to be lost. An official announcement was spread throughout the whole world that whoever brought the princess's diamond necklace would be rewarded with half the kingdom. Then the king's minister, who had become a yogi, went to a shop to sell it where that (other) king regularly made purchases. The minister remained behind at the burning ghats, and the shopkeeper took the necklace and delivered it to the palace. Then the king apprehended the shopkeeper on (charges of) theft. "It wasn't me who stole it; a yogi came to sell it." He sent out (an order) to bring in the yogi. Then ...

\section{The Third Part of the Story Told by Ait Singh Gurung}

Archive No. PK 251, Sound Archive, Humboldt University, Berlin. Recorded at the POW camp in Wünsdorf, Germany, on 29 May 1916 at 16:30. Duration: 01:56 min.

तब जोगीले (तब जोगीले) भन्छन् मेले चोज्याको होइन । मेरो गुरूले दियाको हो । तेरो गुरू कहाँ छ भन् भन्दा मेरो गुरू मसान घाटमा बस्याको छ। तब (तब) राजाले एक गारद पठाए । तब ऊ जोगीले भन्नु लागे कि यो राजमा धेरे बोक्सी रेछ। तब उसे बोक्सीले दियाको हो। उस बोक्सीको बायाँ साप्रामा मेरो यो त्रिशूलको छाप लायाको छ। तब राजाले हुकुम दियो कि जति स्वास्ती छ सबेले कपरा खोलु पर्ला भनी हुकुम दियो। कोही निस्केन । आखिरीमा आफ्रो छोरी मैँयाको निस्के । तब त्रिशूलको छाप देखी तब राजा भन्तु लागे कि यो बोक्सीलाई फाँसी दिनुपई भनी हुकुम दियो। तब जोगीले भन्छ राजा घरमा बोक्सी निस्के भने बाहिर निकाला गर्नु पई । त्यहीं तब मैंयालाई सिन्दूरे जात्रा गरी होदा माथि चढाई तीन दफे बजार घुमाई निकाला गरिदियो । तब राजा मन्त्री पनि गए। ऊ मैँया पनि गए तब राजा ₹ मन्त्री आफ़ो पोशाक लाएर ऊ मैँयालाई लगी राजा रानी भयो बसे ।

The yogi said, "I didn't steal it. My guru gave it (to me)." (The king) asked, "Where is your guru?" "My guru is at the burning ghats." Then the king sent a guard. Then the (other) yogi began (by) saying, "The kingdom has many witches. So it was [one of] the witches that gave it (to me). That witch has the mark of this trishül of mine on her left thigh." Then the king ordered all the women to reveal what was underneath their clothes. No one emerged (as the culprit). Finally his own daughter emerged (as the one). Then the king, seeing the mark of the trishül, ordered the witch to be hanged. Then the yogi said that when a witch emerges from within a palace, she should be expelled. Then

73 The recording picks up the story from here again.

74 A trident. 
and there the princess was set on an elephant, taken three times around the city on a sindure jātrā, ${ }^{75}$ and expelled. Then the king and the minister went their way. The princess, too, went her way. Then the king and the minister changed their clothes, took the princess (with them), and (henceforth the pair) lived as a royal couple.

\section{Appendix 2}

\section{The First Part of the Story Told by Dal Bahadur Gharti}

Archive No. PK 304, Sound Archive, Humboldt University, Berlin. Recorded at the POW camp in Wünsdorf, Germany, on 6 June 1916. Duration: o2:58.

क्वे एक मुलुकमा एक राजा थियो । उस राजाको साथमा बजीर पनि खुब अच्छा जान्ने मन्त्री थियो । तब राजाको पनि एक छोरा थियो। बजीरको पनि एक छोरा थियो। तब राजाको छोरा बजीरको छोरा उनी दुई जना सानेदेखि सँगे सुत्रे, सँगे बस्ने, सँगे खाने, बराबर जहाँ गए पनि दुई जनाको छुटिन कहिले पनि नहुने। तब यसे गरी बढेर जवान भएपछि बनमा शिखार खेल्न जान लागे। तब शिखारमा जाँदा खेरि घोडामाथि सवार भई हिंड्न लागे। तब एक दिन दुई जना शिखारमा गएको थियो। तब एक जझ्लमा शिवको थपना, चोतारा, पीपल, पोखरी, पानी थियो। तब राजाको छोरा बजीरको छोरा दुई जनाले त्यस ठाऊँमा आराम गर्न बसेका थिए। तब एक देशको राजाको छोरी मेयाँ सूरजको मुख पनि नदेख्ने मरदको मुख पनि नदेख्ने बराबर बग्गीमा चढी उसे पोखरीमा अस्नान गर्न जान्थ्यो । तब मेयाँ पनि आयो (आयो) ${ }^{76}$ । राजकुवँर पनि (दुई) उनी दुई जनाको भेट भयो । तो कोई खूबसूरतको थियो। तब राजाको छोराले मैयाँको साथमा बातचीत गर्नको वास्ते कोई किसिमले बोलायो। मेयाँ एक बात पनि नबोली उसे पोखरीमा अस्नान गरी सक्यो। तब राजाको (राजाको) साथमा एक बात पनि नबोली तब (राजा) राजाको जाने बेलामा एक फूल हातमा लिई राजाको छोराको मुखमा हेरी त्यो फूल दाँतले टोक्यो। फेरि कानमा सिउज्यो । फेरि छातिमा लगायो । फेरि पेतालाले टेक्यो (टेक्यो) । बग्गीमा चढी आफ़ा दरबारमा गयो (गयो) । (फेरि गयो) फेरि बजीरको छोराले फेरि हे भाइ! हे भाइ! म त पानी भए पनि हराइ जाने थिएँ (थिएँ) भत्न लाग्यो । बजीरको छोराले भन्यो कि तिमी फिकर नगर्नुहोला (म) मेयाँको सँगमा मेले भेट गराई दिउँका भनेर तब राजाको छोरालाई बहुत सुर्ता पज्यो कि केले भेट होला। तब राजाको (छोराले) छोराले घरमा आयो र दुई जनाले रुपियाँ पेसा घरबाट लिए खर्च खानाको वास्ते दुई जना घोडामाथि चढ़ उसे रानीको देशतिर जान लाए, सवार भएर ।

Once upon a time there was a king in a kingdom. He had a very wise minister. The king also had a son. The minister had a son, too. From childhood onwards, the prince's and the minister's sons were always together while sleeping, sitting [or] eating; no matter where they went, there was no separating them. Thus growing up, they started going hunting in the jungle. They rode horses while hunting. One day the two of them went hunting. There in the jungle was a Shiva temple, a cautārā, a peepal tree, a pond [and] 
[a spring of] water. The prince's and the minister's sons both sat down to take a rest. A princess, a daughter of a king of some country who had never seen the sun or a man, regularly came there in a carriage to bathe in the pond. The princess, too, came. The prince and she met. She was very beautiful. The prince gestured to the princess in some way to have a conversation. The girl didn't utter a word and finished bathing in the pond. She did not speak a word with the prince, but at the time of departing she took a flower in hand, looked the prince in his eyes and bit it with her teeth. She placed it at her ear. Then she placed it against her chest. She then placed it under her foot. She got into the horse carriage and returned to her palace. Then the minister's son said, "O brother! If I were water, I would have evaporated and gone (to where she is)." The minister's son said, "Don't worry. I'll arrange a meeting with the girl." The prince was very troubled, wondering when he would meet her. Then the prince returned home, and the two of them took money from home for daily expenses and food (during the journey) and went by horse to that princess's country.

\section{The Second Part of the Story Told by Dal Bahadur Gharti}

Archive No. PK 305, Sound Archive, Humboldt University, Berlin. Recorded at the POW camp in Wünsdorf, Germany, on 6 June 1916. Duration: o2:58.

तब त्यो फूलको मतलब सोध्र लागे। दन्तपुर भनेको देश हो कर्णवत भनेको मेरो बाबुको नाम हो । पद्मावती मेरो नाम हो। छातिमा लगाएको हामी दुईजना भेट हुमा भनेको हो। दुई जनाले दन्तपुर भनेको देश कता हो भन्दे गए। तब उस देशमा पुगे। उस (उस) देशको मान्छेहरूको सङमा सोध्र लाए कि यो राजाको मेयाँ छ कि छेन भनेर सोधे। त उस देशको मान्छेहरूले (छ भने) छ भने । तब ऊ (त्यस राजाको) त्यस राजाको धाई आमा थियो। तब धाई आमाले खबर (लि) लियो कि भरे राति पूरब तिरको ढोकाबाट पस्तछ। यति मात्रे भन्यो मसित त। तब त्यो खबर ली आउनेलाई पाँच सो रूपियाँ इनाम दियो। तब साँझमा राजाको छोरा रानीको साथमा गयो । तब क्वे दिन उसी दरबारमा भुल्यो। ऊ मन्त्रीले भन्यो कि य[स]लाई अब निकाली आफ़ो घरमा लेजान पई। तब राजाको छोरालाई भन्यो कि लोहा आगोमा तताई त्यसको साप्रामा हानी दगुरी आउनू भनेर राजाको छोराले पनि उसे माफिक गय्यो। तब राजाको छोरा बजीरको छोरा जोगी भए। तब उने दुई जोगीहरूले भत्न लाए कि एस देशमा बडा जादू रहेछन्। आज राति हामी दुई जोगीको सङमा आएको थियो। चिम्टाले हानें (हानें) भागी गयो। तब (त्यस) त्यसको जीउमा कोई किसमको चोट लागेको होला। मरिजानेछ (शायद) शायद भनेर त्यो गाऊँको मान्छेहरू बोल्न लागे। तब ती राजाको मुलुकमा जति मान्छेहरू छन् हल्ला भयो। ती शायद (शायद) कोई बार जोगीले भनेको छ मरिजान्छ कि भनेर राजाले पनि आफ़ा जाहानहरूको साथमा तताश गर्न लाग्यो । आफ़े छोरीको (साथ छोरीको छोरीको) देह देख्यो । छोरीको घाऊ लागेको देख्यो ₹ भन्न लायो कि मेरै छोरी रहेछ जादू होला । यसलाई मरे पनि बाँचे पनि देश निकाला गरिदिनुपछ भनेर सब मन्त्री बोलाई हुकुम दियो कि यो छोरीलाई तिमीहरूले देश निकाला गर भनेर मन्त्रीहरूले देश (निकाला) निकालदिया। तब दुई जनाले (दुई जनाले) बगेर बात, बगेर कुछ, बगेर रुपिया पैसाको ब्याहा गरी आफ़ा दरबारमा गएर बसे । [को राजा भयो को जोगी भयो ?] 77

77 This passage in italics is found in the written version but not on the recording. 
Then he started asking (the minister's son) the meaning of the flower. "Dantapur means (the name of) a country. Karnavat means '(That's) my father's name.' Padmāvatì means '(That's) my name.' Putting (the flower) to her breast means 'We two will meet (again)." Both went on further, asking for the country called Dantapur. They reached that country. They started asking groups of the country's people if the king had a daughter. The people of that country replied yes. In that case, that (woman who had accompanied the princess) was the king's (daughter's) wet nurse. The wet nurse got the information that one (should) enter through a door in the east. She said that this was the only information (she had). The messenger received five hundred rupees (from them) as a reward. Then in the evening the king's son went to meet the princess. For some days he went astray in the palace. The minister said (to himself) that he (the prince) should be gotten out and taken home. Then he told the prince to heat a piece of iron, press it on her thigh and run off. The prince did as instructed. The prince and the minister's son became yogis. Then both started saying that there was much (black) magic in the country. "That night (a witch) came to the two of us. We hit her with an iron tong and she ran away. She must have the mark of a wound on her body. The villagers suspected that she would perhaps die. This rumour spread all over the country. The king also suspected that she would die and started searching for her, together with his family members. He checked his own daughter's body together with (the bodies of the) daughters (of others). He saw the wound and said, "My daughter is (the source of the black) magic. Thinking he had to expel her from the country either alive or dead, he ordered his ministers to expel his daughter from the country, and they did so. Then the two of them married without any negotiations or any (gifts) or any (dowry) money and lived in a palace of their own. [Who became a king and who a yogi? $]^{78}$

\section{Appendix 3}

\section{The Story Told by Gajabal Thapa}

Archive No. PK 248/2, Sound Archive, Humboldt University, Berlin. Recorded at the POW camp in Wünsdorf, Germany, on 29 May 1916. Duration: o1:51.

एक राजाको मुलुकमा अर्के राजा आई भारी लडाई गय्यो। तब उस राजाको लावालस्कर पनि मारिदियो। और राजा पनि मारिदियो । तब उस राजाको रानी और मेयाँ दुई जाना आमाछोरी उम्कीकन तहाँबाटि भागिगयो। तब जाँदा-जाँदा ठूलो बनमा पस्न गयो। तब माझमाझि बनमा बस्यो । तहाँबाट एक अर्के मुलुकको राजाको बाबुछोरा उस बनमा सिकार खेल्न भनी गयाको थियो । तब

\footnotetext{
78 This passage in italics is found in the written version but not on the recording.
} 
उस रानी र मैयाँ गयाके बाटो गयो । तब राजाको बाबुछोरा बात गर्न लाग्यो । अगाडितिर कोही मन्छे आइमाईको जस्तो पाइतो पनि गयाको छ भनी बात पनि गज्यो। तब राजाको बाबुछोराले पनि यो त खासा आइमाईको पाइलो हो भनी बाबुछोराले पनि बाचा बान्न लाग्यो। त बाबुले भन्यो कि ठूलो पाइलावाला लिन्छु भनी छोरालाई सानो पाइलावाला तँलाई भयो भनी बाचा बाँधी गयो ₹ तब जाँदा जाँदा माझामाझी बनमा पुग्न गयो। तब जहाँ रानी ₹ मेयाँ बसीरह्याको थियो उसे ठाऊँमा पुग्यो तब पेले बाटोमा बाचा गरेको बमोजिम बाबुले ठूलो पाइलावाला लियो छोराले सानो पाइलावाला लियो। तब सानो पाइलावाला आमा थियो छोराले लियो ठूलो पाइलावाला छोरी थियो बाबुले लियो । तिनी दुवे जनाको साइनो क्या पज्यो ? यसको अर्थ भनिदिनु म जान्दिन ।

A king came to another king's kingdom and fought a big battle. Then he also killed the armed forces and the king. The queen and the princess of the [killed] king managed to escape from there. They reached a big forest and settled in the middle of it. Meanwhile, a king and his prince from some other country came to that forest to go hunting. They passed the same way that the queen and princess had passed through earlier. The king and his prince had a discussion. They also remarked that there were footsteps of some women who had walked this way. They confirmed that the footsteps were of women and the two of them made an agreement. The father concluded, ["]I will take the one with the long foot; the one with the shorter foot will be yours.["] They moved further to the middle of the forest and reached the place where the queen and the princess were dwelling. As agreed earlier, the father was mated with the one with longer foot and the son was paired with the one with shorter foot. However, the woman with the shorter foot who was taken by the son was the mother, and the woman with longer foot taken by the father was the daughter. Now how are they related? Tell me, I do not know.

\section{Bibliography}

Ahuja, Ravi. "Lost Engagements? Traces of South Asian Soldiers in German Captivity, 1915-1918." In When the War Began We Heard of Several Kings: South Asian Prisoners in World War I Germany, edited by Franziska Roy, Heike Liebau, and Ravi Ahuja, 17-52. New Delhi: Social Science Press, 2011.

Barker, W. Burckhardt, and E. Backhouse Eastwick. The Baitál Pachisí; or, Twenty-five Tales of a Demon: A New Ed. of the Hindi Text, with Each Word Expressed in the Hindústáni Character Immediately under the Corresponding Word in the Nágari; and with a Perfectly Literal English Interlinear Translation, Accompanied by a Free Translation in English at the Foot of Each Page, and Explanatory Notes. Hertford: Stephen Austin, 1855 .

Blackburn, Stuart, and A.K. Ramanujan, eds. Another Harmony: New Essays on the Folklore of India. Berkeley: University of California Press, 1986.

Bolt, David. Gurkhas. London: White Lion, 1975. 
Caplan, Lionel. Warrior Gentlemen: "Gurkhas" in the Western Imagination. Providence, [RI]: Berghahn Books, 1995.

Chhetri, Indrabahadur. "Darjīlin̉kā nepālī kathāharūko pravṛttigat viśleșạ̣ ra mūlyānkan (san 1938-1960)." PhD Diss., University of North Bengal, 2003. http:// hdl.handle.net/106o3/169370, accessed 21 June 2019.

Chudal, Alaka Atreya. "What Can a Song Do to You? A Life Story of a Gurkha Prisoner in World War I." South Asia:Journal of South Asian Studies 43, no. 3 (2020): 392-406. doi: $10.1080 / 00856401.2020 .175^{2974}$.

Chudal, Alaka Atreya. "Storytelling in Prison: Oral Performance of a Gurkha Prisoner of World War I." European Bulletin of Himalayan Research 54 (2O2O):5-36.

Chudal, Alaka Atreya. Gorkhālīyuddhabandī kā lokbhākā ra kathā. Kathmandu: Nepal Academy, 2021.

Chudal, Alaka Atreya. "Nepali Intellectuals in Exile: The History of Nepali Printing in 19th-2oth Century Benares." Journal of South Asian Intellectual History 3 (2012): $1-26$.

Doegen, Wilhelm. Unter fremden Völkern: eine neue Völkerkunde. Berlin: Stollberg, Verl. für Politik u. Wirtschaft, 1925 .

Forbes, Duncan. The Baitāl Pachīsī; or, The Twenty-five Tales of a Demon, London: W.H. Allen, 1857 .

Grierson, G.A. Linguistic Survey of India. Part IX, vol. IV. Calcutta: Superintendent of Government Printing, India, 1916. Available at: http://dsal.uchicago.edu/books/lsi/ lsi.php?volume=9-4\&pages=998\#page $/ 1 /$ mode $/ 1 u p$, accessed October 17, 2017 .

Lange, Britta. "South Asian Soldiers and German Academics: Anthropological, Linguistic and Musicological Field Studies in Prison Camps." In When the War Began We Heard of Several Kings: South Asian Prisoners in World War I Germany, edited by Franziska Roy, Heike Liebau, Ravi Ahuja, 147-184. New Delhi: Social Science Press, 2011.

Liebau, Heike. "Prisoners of War(India)." In 1914-1918-online: International Encyclopedia of the First World War, edited by Ute Daniel, Peter Gatrell, Oliver Janz, Heather Jones, Jennifer Keene, Alan Kramer, Bill Nasson. Issued by Freie Universität Berlin, Berlin 2014-10-o8. Available at: doi: http://dx.doi.org/10.15463/ie1418.10452, accessed May 20, 2020.

Lüders, Heinrich. “Die Gurkas.” In Unter fremden Völkern: eine neue Völkerkunde, edited by Wilhelm Doegen, 126-139. Berlin: Stollberg 1925.

Orsini, Francesca. "Detective Novels: A Commercial Genre in Nineteenth-century North India." In India's Literary History: Essays on the Nineteenth Century, edited by Stuart Blackburn, Vasudha Dalmia, 435-482. Delhi: Permanent Black, 2004. Pradhan, Gupta. Dhümil prșțhaharū. Darjeeling: Gama Prakashan, 2008. 
Riccardi, Theodore. A Nepali Version of the Vetātalañcavimśati. New Haven [CT]: American Oriental Society, 1971.

Roy, Franziska. "South Asian Civilian Prisoners of War in First World War Germany." In When the War Began We Heard of Several Kings: South Asian Prisoners in World War I Germany, edited by Franziska Roy, Heike Liebau, and Ravi Ahuja, 53-95. New Delhi: Social Science Press, 2011.

Sathaye, Adheesh. "The Scribal Life of Folktales in Medieval India." South Asian History and Culture 8, no. 4 (2017), 430-447. doi: 10.1080/19472498.2017.1371511.

Schmidt-Madsen, Jacob. "Repossessing the Past: Authorial Tradition and Scribal Innovation in Śivadāsa's Vetālapañcaviṃśatikā.” Unpublished article, 2014. Available at: https://www.academia.edu/1375526o/Repossessing_the_Past_Authorial_Tradition _and_Scribal_Innovation_in_\%C5\%9Aivad\%C4\%81sas_Vet $\% \mathrm{C}_{4} \% 81$ lapa $\% \mathrm{C}_{3} \% \mathrm{Bic}$ avi\%E1\%B9\%83\%C5\%9Batik\%C4\%81, accessed May 12, 2018.

Śhrestha, Dayaram. "Prārambhik kālko Nepālī sāhityako pūrvapīṭhikā.” In Jagadambā Nepāli Sāhityako Bṛhat Itihās: dosro țheūl, edited by Mādhav Prasād Pokhrel, 379662. Lalitpur: Kamalmani Prakashan.

Upādhyāya, Baladev. Kāśí kī pāṇditya paramparā. Vārāṇasī: Viśvavidyālaya Prakāśan, 1994.

\section{Archival Sources}

Sound Archive (Lautarchiv) of Humboldt University, Berlin: Sound files Archive Nos. PK 246, PK 248/2, PK 25O, PK 251, PK 304, and PK 305.

Archive of the Berlin-Brandenburg Academy of Sciences and Humanities: Heinrich Lüders Collection (Nachlass Heinrich Lüders), Nr. 5: Bd. 2; Nr. 4: Bd. 6; Nr. 4: Bd. 3; Nr. 3: Bd. 2; Nr. 1: Bd. 4. 